\title{
Challenges, issues and trends in fall detection systems
}

\author{
Raul Igual*, Carlos Medrano and Inmaculada Plaza
}

* Correspondence: rigual@unizar.es R\&D\&l EduQTech Group, Escuela Universitaria Politecnica de Teruel, University of Zaragosa, Teruel, Spain

\begin{abstract}
Since falls are a major public health problem among older people, the number of systems aimed at detecting them has increased dramatically over recent years. This work presents an extensive literature review of fall detection systems, including comparisons among various kinds of studies. It aims to serve as a reference for both clinicians and biomedical engineers planning or conducting field investigations. Challenges, issues and trends in fall detection have been identified after the reviewing work. The number of studies using context-aware techniques is still increasing but there is a new trend towards the integration of fall detection into smartphones as well as the use of machine learning methods in the detection algorithm. We have also identified challenges regarding performance under real-life conditions, usability, and user acceptance as well as issues related to power consumption, real-time operations, sensing limitations, privacy and record of real-life falls.
\end{abstract}

Keywords: Fall detection, Review, Smart phones, Assistive technology, Health care

\section{Introduction}

According to the World Health Organization [1] approximately 28-35\% of people aged 65 and over fall each year increasing to $32-42 \%$ for those over 70 years of age. The frequency of falls increases with age and frailty level. In fact, falls exponentially increase with age-related biological changes, which is leading to a high incidence of falls and fall related injuries in the ageing societies. If preventive measures are not taken in the immediate future, the number of injuries caused by falls is projected to be a $100 \%$ higher in 2030. In this context, assistive devices that could help to alleviate this major health problem are a social necessity. Indeed, fall detectors are being actively investigated.

A fall detection system can be defined as an assistive device whose main objective is to alert when a fall event has occurred. In a real-life scenario, they have the potential to mitigate some of the adverse consequences of a fall. Specifically, fall detectors can have a direct impact on the reduction in the fear of falling and the rapid provision of assistance after a fall. In fact, falls and fear of falling depend on each other: an individual who falls may subsequently develop fear of falling and, viceversa, the fear of falling may increase the risk of suffering from a fall [2]. Fear of falling has been shown to be associated with negative consequences such as avoidance of activities, less physical activity, falling, depression, decreased social contact and lower quality of life [3]. The effect of automatic fall detection units on the fear of falling has been studied by Brownsel et al. [4]. They conducted a study with community alarm users who had experienced a fall in

(c) 2013 Igual et al.; licensee BioMed Central Ltd. This is an Open Access article distributed under the terms of the Creative Commons Attribution License (http://creativecommons.org/licenses/by/2.0), which permits unrestricted use, distribution, and reproduction in any medium, provided the original work is properly cited. 
the previous six months. At the end of the study, those who wore the fall detector appropriately reported that they felt more confident and independent, and considered that the detector improved their safety. One of the conclusions of the study was that the fear of falling is likely to be substantially affected by user perception of the reliability and accuracy of the fall detector.

The other important aspect that fall detectors may help to reduce is the time the elderly remain lying on the floor after falling (long lie). This time is one of the key factors that determine the severity of a fall. Many older fallers are unable to get up again without assistance and any subsequent long lie can lead to hypothermia, dehydration, bronchopneumonia and pressure sores [5,6]. This is particularly critical if the person lives alone or loses consciousness after falling. Lord et al. [7] reviewed different studies on the long lie. They found that the long lie is a marker of weakness, illness and social isolation and is associated with high mortality rates among the elderly. More than $20 \%$ of patients admitted to hospital because of a fall had been on the ground for an hour or more, and even if there was no direct injury from the fall, their morbidity rates within 6 months were very high. Robust fall detectors may have the potential to diminish this long lie. A robust fall detector is one that is able to classify the falls as falls and the non-falls as non-falls even under real life conditions. If a fall event occurs and the system does not detect it, the consequences can be dramatic: the person can remain lying on the floor for a long time with all that this implies. In addition, the loss of confidence in the system may eliminate the benefits of the detector on the fear of falling. By contrast, if the system reports an excessive number of false activations, caregivers may perceive it as ineffective and useless, which may lead to device rejection. But robustness is not easy to achieve. Although several commercial products are available on the market, the fact is that they are not widely used and do not have a real impact on the elders' lives yet $[8,9]$. Besides, the vast majority of their potential users do not know of their existence. However, when the concept of fall detection is presented, they find in it a great potential to improve their security and safety in home.

For these and many more reasons, the number of studies on fall detection has increased dramatically over recent years. Unfortunately, there are not many reviews on fall detection. The work of Noury et al. [10], which appeared in 2008, can be considered the first one in this field. Shortly thereafter, Perry et al. [11] published a similar analysis. These studies provided a general overview of the fall detection status, but it has changed greatly since they were published, and the current fall detection trends have little in common with those of previous years. Mubashir et al. [12] is more recent, but it includes only 2 papers from 2011 and lacks later papers anyway, for instance many smartphone-based detectors. In our study, we do not present a detailed discussion of each paper, like [12], but rather we show the information schematically by means of tables including relevant information for people conducting research in this field: the types of falls used in the simulations, the number of users involved in the tests, whether they include data from older people, detectors' performance, methods and features used for classification, etc. In addition we have performed a longitudinal study to identify the current trends. We have also included our view of the challenges that fall detection faces and we have highlighted the critical issues that can compromise its use in real-world scenarios. We hope that our work will serve as a reference for both clinicians and biomedical engineers planning or conducting field investigations. 
The study has been carried out through the analysis of several journal articles and conference proceedings. A search of IEEE Xplore, PubMed, MEDLINE, Google Scholar, and Web of Knowledge has been conducted. The search strategy included either "fall detection", "fall detector", "detection of falls", "automatic fall detection", "fall detection mobile phones", "fall detection accelerometers", "fall detection context" or "fall events" as the keywords. References were searched by hand and further relevant papers identified from their citations. A total of 327 studies on fall detection were found, which were then categorized into different groups (see section Classification of fall detection systems). Some of them were selected for a further analysis that is presented in this paper. The selection criteria were:

- Firstly, we considered the most cited study per year in each category, from 2005 to 2012, according to the ranking provided by the Web of Knowledge.

- Secondly, among the remaining studies, we made a personal selection in order to obtain those works that may help to identify the challenges, issues and trends in fall detection as well as to provide a comprehensive vision of the different detection techniques and the current status of this field. Only studies including some experimental results or pioneering investigations have been considered.

The rest of this paper is organized as follows: firstly, a classification of fall detection systems is presented, distinguishing between context-aware systems and wearable devices; secondly, we discuss the challenges, issues and trends in fall detection.

\section{Classification of fall detection systems}

The literature reviewed provides evidence of the lack of a common approach. Noury et al. [10] classify the different studies on fall detection according to whether they only focus on the detection of the impact shock, or they also include the detection of the postfall phase. By contrast, Mubashir et al. [12] divide fall detectors into three categories: wearable device based, ambience sensor based and camera (vision) based. Perry et al. [11] group them into three categories: methods that measure acceleration, methods that measure acceleration combined with other methods, and methods that do not measure acceleration.

Essentially, the structure of all fall detection systems is always similar. Their main objective is to discriminate between fall events and activities of daily living (ADL). This is not an easy task as certain ADL, like sitting down or going from standing position to lying down, have strong similarities to falls. Thus, in order to test a fall detector, it is necessary to collect data from falls and ADL, which can be real (very difficult, especially for falls) or simulated by young volunteers (a feasible option adopted by most authors). These data are recorded by sensors and can be in form of acceleration signals, images, pressure signals, etc. Then, they are processed and classified using a fall detection technique capable of distinguishing between falls and ADL. In most cases, the performance of the detector is expressed in terms of sensitivity (SE) and specificity (SP). The sensitivity is the ability of a detector to correctly classify a fall as a fall, while the specificity is the ability of a detector to correctly classify an ADL as ADL [13].

After reviewing the literature, we conclude that fall detectors can be broadly categorized into two types: context-aware systems and wearable devices. The first category includes 
151 studies, while 197 papers belong to the second one. Twenty-one studies have been included in both categories since they use a combination of techniques. Next sections investigate some of the most relevant studies in both groups.

\section{Context-aware systems}

These systems use sensors deployed in the environment to detect falls. Their main advantage is that the person does not need to wear any special device. However, their operation is limited to those places where the sensors have been previously deployed [14].

Among all the possible types of sensors, the most common are cameras, floor sensors, infrared sensors, microphones and pressure sensors. Video-based systems can be considered as a subcategory in this group as they use computer vision techniques that differ from the rest of the detection methods. Table 1 compares some of the most significant works in this area. For the comparison, we suggest a set of 9 items: the year of their publication, a brief description of the fall detection technique, the features extracted to perform the fall detection, the fall types considered in the study, the subjects involved in the testing phase, the type of sensor used and whether they include data from older people or not.

There is a high variability in detection techniques as they are dependent on the type of sensor used. All methods start with a feature extraction, for example, the ratio of people's height and weight [15], the edge points from the silhouette of a person [14], changes in illumination [16], the orientation of the main axis of the person [17], the width, height and depth of the human posture [18], the skin colour to detect people [19], etc. Then these features are compared and classified to distinguish normal activities from real falls using different techniques (Table 2). At present, lots of different features have been examined and none of them prevails over the rest since they give similar results and no comparison has been done.

The number of subjects involved in the tests is still low if compared to accelerationbased studies (next section). In addition, common to all of these works is the absence of older people during the test period.

Although most of the studies report relatively high accuracies, the experimental findings may not be generalized since there are significant limitations in the test dataset. For example, video-based systems only consider one or two specific sequences in controlled environments $[14,15,17,19-24]$ and other studies with different types of sensors (pressure [25], infrared [18], etc.) only use a few tens of data collected from some young volunteers. Longer real-world tests could probably lead to more realistic results.

Privacy concerns in context aware systems are not minor problems. Methods to protect privacy are dependent on the type of sensor used. In the extreme case of video-based technology, some authors have opted to obscure or distort the person's appearance in the video to ensure privacy [26]. Although privacy should already be considered in the design stage [27], not all the studies have followed this approach, which is a clear sign that some context aware systems are mainly focused on the technological development rather than on a real-world deployment.

If we focus on the fall detection techniques used in the different studies, a variety of approaches can be found. Table 2 summarizes the contributions of the different authors.

In general, the structure of all methods is very similar. Most of them start with an object detection that can be performed through a background subtraction in the video-based 
Table 1 Comparison of context-aware systems

\begin{tabular}{|c|c|c|c|c|c|c|c|c|c|}
\hline Article & Year & Basis & Features used for fall detection & Fall types & Subjects & $\begin{array}{l}\text { Declared } \\
\text { performance }\end{array}$ & $\begin{array}{l}\text { Type of } \\
\text { sensor }\end{array}$ & $\begin{array}{l}\text { Elders } \\
\text { Yes/No }\end{array}$ & Comments \\
\hline \multirow[t]{2}{*}{ Lee et al. [20] } & \multirow[t]{2}{*}{2005} & \multirow{2}{*}{$\begin{array}{l}\text { Vision-based method } \\
\text { for monitoring falls } \\
\text { at home }\end{array}$} & \multirow{2}{*}{$\begin{array}{l}\text { State and geometrical orientation } \\
\text { of the silhouette at time } t \text {, spatial } \\
\text { orientation and speed of the centre } \\
\text { of the silhouette }\end{array}$} & \multirow{2}{*}{$\begin{array}{l}\text { Fall lying down } \\
\text { in a 'stretched' } \\
\text { position and fall } \\
\text { lying down in a } \\
\text { 'tucked' position }\end{array}$} & \multirow{2}{*}{$\begin{array}{l}21 \text { subjects } \\
\text { (age } 20-40 \text { ) }\end{array}$} & SP: $80.5 \%$ & \multirow[t]{2}{*}{ Camera } & \multirow[t]{2}{*}{ No } & \multirow{2}{*}{$\begin{array}{l}\text { Personalized thresholds } \\
\text { are established based } \\
\text { on the height of the } \\
\text { subjects }\end{array}$} \\
\hline & & & & & & SE: 93.9\% & & & \\
\hline Miaou et al. [15] & 2006 & $\begin{array}{l}\text { Customized fall detection } \\
\text { system using omni- } \\
\text { camera } \\
\text { images }\end{array}$ & $\begin{array}{l}\text { The ratio of people's height } \\
\text { and weight }\end{array}$ & Not specified & 20 subjects & $\begin{array}{l}\text { With personal } \\
\text { information: } \\
\text { SP: } 86 \% \text { SE: } 90 \%\end{array}$ & Camera & No & $\begin{array}{l}\text { Determining a proper } \\
\text { threshold statistically } \\
\text { for different ranges of } \\
\text { height or weight alone } \\
\text { does not improve the } \\
\text { system performance }\end{array}$ \\
\hline Vishwakarma et al. [21] & 2007 & $\begin{array}{l}\text { Automatic detection of } \\
\text { human fall in video }\end{array}$ & $\begin{array}{l}\text { Aspect ratio, horizontal and vertical } \\
\text { gradient distribution of object in XY } \\
\text { plane and fall angle }\end{array}$ & $\begin{array}{l}\text { Sideways, } \\
\text { forward, } \\
\text { backward falls }\end{array}$ & 1 subject & SP: $100 \%$ SE: $100 \%$ & Camera & No & $\begin{array}{l}\text { Both indoor and } \\
\text { outdoor video } \\
\text { containing different } \\
\text { types of possible falls } \\
\text { are taken }\end{array}$ \\
\hline Cucchiara et al. [19] & 2007 & $\begin{array}{l}\text { A multi-camera vision } \\
\text { system for detecting and } \\
\text { tracking people and } \\
\text { recognizing dangerous } \\
\text { behaviours }\end{array}$ & $\begin{array}{l}\text { Geometrical and colour features } \\
\text { together with the projection of the } \\
\text { silhouette's shape on the } x \text { and } y \text { axes. }\end{array}$ & Not specified & Not specified & $\begin{array}{l}\text { Difficulties with } \\
\text { occlusions are } \\
\text { reported }\end{array}$ & Camera & No & $\begin{array}{l}\text { If a fall is suspected it } \\
\text { delivers live video } \\
\text { streams to clinicians in } \\
\text { order to check the } \\
\text { validity of a received } \\
\text { alarm }\end{array}$ \\
\hline Fu et al. [16] & 2008 & $\begin{array}{l}\text { Contrast vision system } \\
\text { designed to detect } \\
\text { accidental falls }\end{array}$ & Change in illumination & $\begin{array}{l}\text { Backward, } \\
\text { forward and } \\
\text { sideways falls }\end{array}$ & 3 subjects & $\begin{array}{l}3 \text { possible } \\
\text { scenarios } \\
\text { evaluated with } \\
\text { positive results }\end{array}$ & $\begin{array}{l}\text { Contrast } \\
\text { vision sensor }\end{array}$ & No & $\begin{array}{l}\text { Instantaneous motion } \\
\text { vectors are computed } \\
\text { and fall hazards are } \\
\text { immediately reported } \\
\text { with low } \\
\text { computational effort }\end{array}$ \\
\hline Hazelhoff et al. [17] & 2008 & $\begin{array}{l}\text { Real-time vision system to } \\
\text { detect fall incidents in } \\
\text { unobserved home } \\
\text { situations }\end{array}$ & $\begin{array}{l}\text { The orientation of the main axis } \\
\text { of the person and the ratio of the } \\
\text { variances in horizontal and vertical } \\
\text { direction Skin colour }\end{array}$ & Not specified & $\begin{array}{l}\text { At least } 2 \\
\text { subjects }\end{array}$ & $\begin{array}{l}\text { SE: } 100 \% \text { when } \\
\text { large occlusions } \\
\text { are absent }\end{array}$ & Camera & No & $\begin{array}{l}\text { The position of the } \\
\text { head is taken into } \\
\text { account in order to } \\
\text { obtain a high } \\
\text { robustness }\end{array}$ \\
\hline
\end{tabular}


Table 1 Comparison of context-aware systems (Continued)

\begin{tabular}{|c|c|c|c|c|c|c|c|c|c|}
\hline \multirow[t]{2}{*}{ Anderson et al. [22] } & \multirow[t]{2}{*}{2009} & \multirow[b]{2}{*}{$\begin{array}{l}\text { 3D representation of } \\
\text { humans (voxels) using } \\
\text { multiple cameras. Two } \\
\text { levels of fuzzy logic } \\
\text { determines first a state } \\
\text { and then activities } \\
\text { (fi. a fall) }\end{array}$} & \multirow{2}{*}{$\begin{array}{l}\text { At low level: silhouettes from each } \\
\text { camera, to build a set of voxels. At } \\
\text { an intermediate level: centroid, height, } \\
\text { major orientation of the body and } \\
\text { similarity of the major orientation with } \\
\text { the ground plane normal. }\end{array}$} & \multirow[b]{2}{*}{$\begin{array}{l}\text { At least, falls } \\
\text { forward, } \\
\text { backwards, and } \\
\text { to the side (with } \\
\text { recovery, } \\
\text { attempting to } \\
\text { get back up, } \\
\text { lying } \\
\text { motionless) }\end{array}$} & \multirow[t]{2}{*}{ Not specified } & SE: $100 \%$ & \multirow[t]{2}{*}{ Camera } & \multirow[t]{2}{*}{ No } & \multirow[b]{2}{*}{$\begin{array}{l}\text { The system can } \\
\text { produce sentences } \\
\text { like "the person is on- } \\
\text { the-ground in the } \\
\text { kitchen for a } \\
\text { moderate amount of } \\
\text { time" }\end{array}$} \\
\hline & & & & & & SP: $93.75 \%$ & & & \\
\hline Lie et al. [23] & 2010 & $\begin{array}{l}\text { Vision fall detection } \\
\text { system considering } \\
\text { privacy issues }\end{array}$ & $\begin{array}{l}\text { The ratio and difference of human } \\
\text { body silhouette bounding box height } \\
\text { and width }\end{array}$ & Not specified & $\begin{array}{l}15 \text { subjects } \\
\text { (age } 24-60 \text { ) }\end{array}$ & Accuracy $84.44 \%$ & Camera & No & $\begin{array}{l}\text { Activities are divided } \\
\text { into three categories: } \\
\text { standing posture, } \\
\text { temporary posture } \\
\text { and lying down } \\
\text { posture }\end{array}$ \\
\hline \multirow[t]{2}{*}{ Rimminen et al. [28] } & \multirow[t]{2}{*}{2010} & \multirow{2}{*}{$\begin{array}{l}\text { Fall-detection method } \\
\text { using a floor sensor } \\
\text { based on near-field } \\
\text { imaging }\end{array}$} & \multirow{2}{*}{$\begin{array}{l}\text { Features related to the near-field } \\
\text { imaging floor (the number of } \\
\text { observations, the sum of magnitudes } \\
\text { and dimensional features) }\end{array}$} & \multirow[b]{2}{*}{$\begin{array}{l}\text { Backward to sit, } \\
\text { backward to } \\
\text { lateral, to supine, } \\
\text { onto knees, arm } \\
\text { protect, to } \\
\text { prone, rotate } \\
\text { right and left, } \\
\text { right and left } \\
\text { lateral }\end{array}$} & \multirow[t]{2}{*}{10 subjects } & SE: $91 \%$ & \multirow{2}{*}{$\begin{array}{l}\text { Near-field } \\
\text { image } \\
\text { sensor }\end{array}$} & \multirow[t]{2}{*}{ No } & \multirow{2}{*}{$\begin{array}{l}\text { The fall-detection } \\
\text { performance is valid } \\
\text { for multiple people in } \\
\text { the same room }\end{array}$} \\
\hline & & & & & & SP: $91 \%$ & & & \\
\hline \multirow[t]{2}{*}{ Tzeng et al. [25] } & \multirow[t]{2}{*}{2010} & \multirow{2}{*}{$\begin{array}{l}\text { A system that adjusts the } \\
\text { detection sensitivity on a } \\
\text { case-by-case basis to } \\
\text { reduce unnecessary } \\
\text { alarms }\end{array}$} & Floor pressure signal & \multirow{2}{*}{$\begin{array}{l}\text { Backward, } \\
\text { forward and } \\
\text { sideways falls }\end{array}$} & \multirow[t]{2}{*}{ Not specified } & SP: 96.7\% & \multirow{2}{*}{$\begin{array}{l}\text { Pressure/ } \\
\text { infrared } \\
\text { sensors }\end{array}$} & \multirow[t]{2}{*}{ No } & \multirow{2}{*}{$\begin{array}{l}\text { The floor pressure } \\
\text { sensor is combined } \\
\text { with the infrared } \\
\text { sensor }\end{array}$} \\
\hline & & & $\begin{array}{l}\text { Image features: standard deviation } \\
\text { of vertical projection histogram, } \\
\text { standard deviation of horizontal } \\
\text { projection histogram, and aspect ratio }\end{array}$ & & & SE: $100 \%$ & & & \\
\hline \multirow[t]{2}{*}{ Diraco et al. [24] } & \multirow[t]{2}{*}{2010} & \multirow{2}{*}{$\begin{array}{l}\text { An active vision system } \\
\text { for the detection of falls } \\
\text { and the recognition of } \\
\text { postures for elderly } \\
\text { homecare applications. }\end{array}$} & \multirow{2}{*}{$\begin{array}{l}\text { People's silhouette and their } \\
\text { centre-of-mass }\end{array}$} & \multirow{2}{*}{$\begin{array}{l}\text { Backward falls, } \\
\text { forward falls, } \\
\text { lateral falls }\end{array}$} & \multirow[t]{2}{*}{ Not specified } & SE: $80 \%$ & \multirow[t]{2}{*}{ Camera } & \multirow[t]{2}{*}{ No } & \multirow{2}{*}{$\begin{array}{l}\text { Information about the } \\
\text { 3D position of the } \\
\text { subject is combined } \\
\text { with the detection of } \\
\text { inactivity. }\end{array}$} \\
\hline & & & & & & SP: $97.3 \%$ & & & \\
\hline
\end{tabular}




\begin{tabular}{|c|c|c|c|c|c|c|c|c|c|}
\hline & & & & & & & & & $\begin{array}{l}\text { An approach for } \\
\text { posture recognition is } \\
\text { proposed }\end{array}$ \\
\hline Rougier et al. [14] & 2011 & $\begin{array}{l}\text { A vision system based on } \\
\text { analyzing human shape } \\
\text { deformation }\end{array}$ & $\begin{array}{l}\text { Some edge points from the } \\
\text { silhouette of the person }\end{array}$ & $\begin{array}{l}\text { Forward falls, } \\
\text { backward falls, } \\
\text { falls when } \\
\text { inappropriately } \\
\text { sitting down, } \\
\text { loss of balance }\end{array}$ & Not specified & $\begin{array}{l}\text { Accuracy (falls and } \\
\text { ADL correctly } \\
\text { classified): } 98 \%\end{array}$ & Camera & No & $\begin{array}{l}\text { The fall impact is an } \\
\text { important feature to } \\
\text { detect a fall, but the } \\
\text { lack of movement } \\
\text { after the fall is crucial } \\
\text { for robustness }\end{array}$ \\
\hline \multirow[t]{2}{*}{ Li et al. [29] } & \multirow[t]{2}{*}{2012} & \multirow[t]{2}{*}{$\begin{array}{l}\text { Acoustic fall detection } \\
\text { system }\end{array}$} & \multirow[t]{2}{*}{$\begin{array}{l}\text { Acoustic signals sampled } \\
\text { at } 20 \mathrm{KHz}\end{array}$} & \multirow{2}{*}{$\begin{array}{l}\text { Backward, } \\
\text { forward and } \\
\text { sideways falls } \\
\text { (balance, lose } \\
\text { consciousness, } \\
\text { trip, slip, reach } \\
\text { chair, couch) }\end{array}$} & \multirow{2}{*}{$\begin{array}{l}3 \text { subjects } \\
\text { ( } 2 \text { female, } 1 \text { male, } \\
\text { ages } 30,32,46)\end{array}$} & SE: $100 \%$ & \multirow[t]{2}{*}{$\begin{array}{l}\text { Array of } \\
\text { microphones }\end{array}$} & \multirow[t]{2}{*}{ No } & $\begin{array}{l}\text { The source of the } \\
\text { sound is located. }\end{array}$ \\
\hline & & & & & & & & & $\begin{array}{l}\text { The performance of } \\
\text { the acoustic detector } \\
\text { is evaluated using } \\
\text { simulated fall and } \\
\text { nonfall sounds }\end{array}$ \\
\hline Mastorakis et al. [18] & 2012 & $\begin{array}{l}\text { Real-time fall detection } \\
\text { system based on the } \\
\text { Kinect sensor }\end{array}$ & $\begin{array}{l}\text { The width, height and depth } \\
\text { of the human posture, which } \\
\text { define a 3D bounding box }\end{array}$ & $\begin{array}{l}\text { Backward, } \\
\text { forward and } \\
\text { sideways falls }\end{array}$ & 8 subjects & $\begin{array}{l}\text { All falls were } \\
\text { accurately } \\
\text { detected }\end{array}$ & $\begin{array}{l}\text { Infrared } \\
\text { sensor }\end{array}$ & No & $\begin{array}{l}\text { The system requires } \\
\text { no pre-knowledge of } \\
\text { the scene and three } \\
\text { parameters to } \\
\text { operate; the width, } \\
\text { height and depth of } \\
\text { the subject }\end{array}$ \\
\hline Zhang et al. [27] & 2012 & $\begin{array}{l}\text { Privacy Preserving } \\
\text { Automatic Fall Detection }\end{array}$ & Deformation and person's height & $\begin{array}{l}\text { Fall from chair, } \\
\text { fall from } \\
\text { standing }\end{array}$ & 5 subjects & Accuracy $94 \%$ & $\begin{array}{l}\text { RGBD } \\
\text { cameras }\end{array}$ & No & $\begin{array}{l}\text { The system can } \\
\text { handle special cases } \\
\text { such as light turning } \\
\text { off (insufficient } \\
\text { illumination) }\end{array}$ \\
\hline
\end{tabular}


Table 2 Fall detection techniques in the context-aware studies

\begin{tabular}{|c|c|c|c|c|c|}
\hline & \multicolumn{5}{|c|}{ Fall detection method } \\
\hline & $1^{\text {st }}$ step & $2^{\text {nd }}$ step & $3^{\text {rd }}$ step & $4^{\text {th }}$ step & $5^{\text {th }}$ step \\
\hline Lee et al. [20] & $\begin{array}{l}\text { Adaptive background } \\
\text { subtraction to detect the } \\
\text { object of interest }\end{array}$ & $\begin{array}{l}\text { Image processing using } \\
\text { a connective-component } \\
\text { labelling technique, with } \\
\text { the end product being a } \\
\text { 'blob' or silhouette }\end{array}$ & Feature extraction & $\begin{array}{l}\text { Determination of the threshold } \\
\text { values for each of the features } \\
\text { based on the height of the users }\end{array}$ & \\
\hline Miaou et al. [15] & $\begin{array}{l}\text { Background subtraction } \\
\text { to detect the objects. }\end{array}$ & $\begin{array}{l}\text { Image processing: erosion } \\
\text { and dilatation, connected } \\
\text { component labelling } \\
\text { technique }\end{array}$ & $\begin{array}{l}\text { Feature extraction } \\
\text { (height and width of } \\
\text { object's silhouettes) }\end{array}$ & $\begin{array}{l}\text { Simple threshold-based decision } \\
\text { algorithm for fall detection }\end{array}$ & \\
\hline Vishwakarma et al. [21] & $\begin{array}{l}\text { Patient detection } \\
\text { (adaptive background } \\
\text { subtraction method using } \\
\text { Gaussian mixture model) }\end{array}$ & Feature extraction & $\begin{array}{l}\text { Fall detection using aspect } \\
\text { ratio and pixel's gradient } \\
\text { distribution and applying } \\
\text { rule-based decisions }\end{array}$ & $\begin{array}{l}\text { Fall confirmation using the fall } \\
\text { angle and applying rule-based } \\
\text { decisions }\end{array}$ & \\
\hline Cucchiara et al. [19] & $\begin{array}{l}\text { Extraction of moving objects } \\
\text { using background suppression } \\
\text { with selective and adaptive } \\
\text { update }\end{array}$ & $\begin{array}{l}\text { Tracking algorithm: } \\
\text { A probabilistic and } \\
\text { appearance-based tracking }\end{array}$ & $\begin{array}{l}\text { Classification as people } \\
\text { of tracks that satisfy some } \\
\text { geometrical and colour } \\
\text { constraints }\end{array}$ & $\begin{array}{l}\text { Posture classifier based on the } \\
\text { projection histograms computed } \\
\text { over the temporal probabilistic } \\
\text { maps obtained by the tracker }\end{array}$ & $\begin{array}{l}\text { Hidden Markov Models formulation } \\
\text { is adopted to classify the posture }\end{array}$ \\
\hline Fu et al. [16] & $\begin{array}{l}\text { Extraction of changing pixels } \\
\text { (motion events) from the } \\
\text { background }\end{array}$ & $\begin{array}{l}\text { A lightweight algorithm } \\
\text { computes the instantaneous } \\
\text { motion vectors }\end{array}$ & $\begin{array}{l}\text { Fall events are reported } \\
\text { using the temporal average } \\
\text { of the motion events }\end{array}$ & & \\
\hline Hazelhoff et al. [17] & $\begin{array}{l}\text { Object segmentation: } \\
\text { (background subtraction and } \\
\text { connection of information } \\
\text { components) }\end{array}$ & $\begin{array}{l}\text { Object tracking: the tracker } \\
\text { can mark objects as non-human, } \\
\text { which are identified based on } \\
\text { size and absence of both motion } \\
\text { and a head region }\end{array}$ & $\begin{array}{l}\text { PCA-based feature extraction: } \\
\text { the direction of the principal } \\
\text { component and the variance } \\
\text { ratio are extracted }\end{array}$ & $\begin{array}{l}\text { Fall detection: using a multi-frame } \\
\text { Gaussian classifier }\end{array}$ & $\begin{array}{l}\text { Head tracking using skin-colour } \\
\text { model to confirm the fall }\end{array}$ \\
\hline Anderson et al. [22] & $\begin{array}{l}\text { Silhouette extraction from } \\
\text { each camera. Then, a 3D } \\
\text { representation of the body } \\
\text { is constructed }\end{array}$ & $\begin{array}{l}\text { Extraction of centroid, height, } \\
\text { major orientation of the body } \\
\text { and similarity of the major } \\
\text { orientation with the ground } \\
\text { plane normal }\end{array}$ & $\begin{array}{l}\text { Human state inferred using } \\
\text { fuzzy logic ( } 3 \text { states: upright, } \\
\text { on-the-ground and in-between) }\end{array}$ & $\begin{array}{l}\text { Information in sequences of states } \\
\text { is reduced by linguistic summarization } \\
\text { to produce human readable sentences }\end{array}$ & $\begin{array}{l}\text { Fall detected by a second level } \\
\text { of fuzzy logic, taking inputs from } \\
\text { a single summary: average state, } \\
\text { time duration, speed, oscillation, etc. }\end{array}$ \\
\hline
\end{tabular}




\section{Table 2 Fall detection techniques in the context-aware studies (Continued)}

\begin{tabular}{|c|c|c|c|c|c|}
\hline Lie et al. [23] & $\begin{array}{l}\text { Human body identification } \\
\text { using frame differencing approach }\end{array}$ & $\begin{array}{l}\text { Image processing: mean filter } \\
\text { to make the image more smooth, } \\
\text { thresholding to obtain a binary } \\
\text { image, connected component } \\
\text { labelling }\end{array}$ & $\begin{array}{l}\text { Features extraction and } \\
\text { reduction of upper limb } \\
\text { activities effect }\end{array}$ & $\begin{array}{l}\text { k-nearest neighbour classifier for } \\
\text { human body postures classification }\end{array}$ & $\begin{array}{l}\text { Fall event detection flow: } \\
\text { the decision of a fall incident } \\
\text { is determined by the event } \\
\text { transition and time difference } \\
\text { between events }\end{array}$ \\
\hline Rimminen et al. [28] & $\begin{array}{l}\text { Estimate the position of the } \\
\text { subject using the near-field } \\
\text { image sensor observations }\end{array}$ & $\begin{array}{l}\text { Tracking (Kalman filter) and } \\
\text { multi-target tracking (Rao- } \\
\text { Blackwellized Monte Carlo data } \\
\text { association algorithm) }\end{array}$ & $\begin{array}{l}\text { Features extraction related } \\
\text { to the NFI floor }\end{array}$ & $\begin{array}{l}\text { Modelling of the state evolution } \\
\text { as a two-state Markov chain } \\
\text { (falling, getting up) }\end{array}$ & $\begin{array}{l}\text { Pose estimation using Bayesian } \\
\text { filtering. It combines the prior } \\
\text { model with information from } \\
\text { the features }\end{array}$ \\
\hline Tzeng et al. [25] & $\begin{array}{l}\text { Fall suspection: Thresholding } \\
\text { of the floor pressure signal }\end{array}$ & $\begin{array}{l}\text { If the floor preassure exceeds a } \\
\text { given threshold: Image capture }\end{array}$ & $\begin{array}{l}\text { Background subtraction } \\
\text { through an image thresholding. } \\
\text { Objects labelling and expansion } \\
\text { (morphological operations) }\end{array}$ & Image features extraction & $\begin{array}{l}\text { Combination of the floor } \\
\text { pressure signal and image } \\
\text { features to report on a fall }\end{array}$ \\
\hline Diraco et al. [24] & Camera calibration & $\begin{array}{l}\text { Background modelling using } \\
\text { Mixture of Gaussians method }\end{array}$ & $\begin{array}{l}\text { Moving regions detection } \\
\text { (Bayesian segmentation) and } \\
\text { segmented blobs refining } \\
\text { (morphological operations and } \\
\text { connected components) }\end{array}$ & $\begin{array}{l}\text { Fall suspection: The distance } \\
\text { of the centroid from the floor } \\
\text { plane is lower than a prefixed value }\end{array}$ & $\begin{array}{l}\text { Fall confirmation if an } \\
\text { unchangeable situation persists } \\
\text { for at least } 4 \text { seconds }\end{array}$ \\
\hline Rougier et al. [14] & $\begin{array}{l}\text { Silhouette detection } \\
\text { (foreground segmentation } \\
\text { method) and edge points } \\
\text { extraction (Canny edge } \\
\text { detector) }\end{array}$ & $\begin{array}{l}\text { Silhouette edge points } \\
\text { matching through the video } \\
\text { sequence }\end{array}$ & $\begin{array}{l}\text { Shape analysis using the mean } \\
\text { matching cost and the full } \\
\text { Procrustes distance }\end{array}$ & $\begin{array}{l}\text { Fall classification: Gaussian mixture } \\
\text { model, based on shape deformation } \\
\text { during the fall and the subsequent } \\
\text { lack of movement }\end{array}$ & \\
\hline Li et al. [29] & $\begin{array}{l}\text { Locate the position of the } \\
\text { sound source }\end{array}$ & $\begin{array}{l}\text { Beamforming to enhance the } \\
\text { sound signal using the } \\
\text { estimated source position }\end{array}$ & $\begin{array}{l}\text { Mel-frequency cepstral } \\
\text { coefficients features are } \\
\text { extracted from the sound signal }\end{array}$ & $\begin{array}{l}\text { A nearest neighbour classifier } \\
\text { determines if the sound is from } \\
\text { a fall }\end{array}$ & \\
\hline Mastorakis et al. [18] & $\begin{array}{l}\text { Feature extraction: width, } \\
\text { height and depth of the } \\
\text { human posture }\end{array}$ & $\begin{array}{l}\text { Obtaining of the velocities of } \\
\text { height and the composite } \\
\text { vector of width and depth }\end{array}$ & $\begin{array}{l}\text { When both velocities exceed } \\
\text { particular thresholds fall } \\
\text { initiation is detected }\end{array}$ & $\begin{array}{l}\text { Inactivity detection: a fall is detected } \\
\text { if the height velocity is less than a } \\
\text { certain threshold }\end{array}$ & \\
\hline Zhang et al. [27] & $\begin{array}{l}\text { Kinematic Model Based } \\
\text { Feature Extraction from } \\
\text { Depth Channel }\end{array}$ & $\begin{array}{l}\text { Person tracking by background } \\
\text { subtraction }\end{array}$ & $\begin{array}{l}\text { Histogram represented } \\
\text { features }\end{array}$ & $\begin{array}{l}\text { Hierarchy Support Vector Machine } \\
\text { classification }\end{array}$ & \\
\hline
\end{tabular}


systems [14,15,17,19-23], or from the information provided by the sensors' observation $[28,29]$. Some methods also consider a tracking algorithm to filter objects' position $[17,19,27,28]$. Then, some features of the detected objects are extracted (Table 1), which should have sufficient discriminative power to identify the fall events. They are used to classify the events as falls or non-falls using a wide range of techniques: Gaussian Mixture Model [14], Rule-based Techniques [21], Multi-frame Gaussian Classifier [17], Bayesian Filtering [28], Nearest-neighbour Rule [23,29], Hidden Markov Models [19], Thresholding Techniques [15,20,25], Fuzzy Logic [22], etc. Some studies confirm that a fall has occurred by performing inactivity detection in the postfall phase [14,18,24].

As a result of this extensive literature search, we found that lots of strategies have been adopted, although currently there is no standardized context-aware technique that was widely accepted by the research community in this field.

\section{Wearable devices}

They can be defined as miniature electronic sensor-based devices that are worn by the bearer under, with or on top of clothing [30]. The vast majority of wearable fall detectors are in the form of accelerometer devices (186 out of 197). Some of them also incorporate other sensors such as gyroscopes to obtain information about the patient's position. The use of applications based on accelerometers and gyroscopes in gait and balance evaluation, fall risk assessment and mobility monitoring has been actively explored [31]. This trend has increased over the last years due to the availability of cheap embedded sensors included in smartphones. In this paper, we classify the different studies using wearable devices according to whether or not sensors are built into smartphones, 30 and 156 papers respectively. The next two sections provide more details about these subgroups.

\section{Accelerometer attached to the body}

Acceleration data are collected during falls using independent tri-axial accelerometers attached to different parts of the body. A review of several research studies was conducted. For the purpose of comparison, Table 3 examines the most relevant works. The fields are the same as in section Context-aware systems, including a new item with the accelerometer placement on the body. Since Table 3 is only focused on acceleration-based systems, the possible techniques for fall detection are reduced to just two: i) threshold-based methods, TBM, in which a fall is reported when the acceleration peaks, valleys or other shape features reach predefined thresholds; ii) machine learning methods, MLM [32]. The aim is to visualize progress in research over the last years.

Most of the existing works use thresholding techniques for automatic fall detection [9,33-41], although the machine learning approach has increased its influence since 2010 [42-44]. The methods applied include Support Vector Machine [42,44-46], Regrouping Particle Swarm Optimization, Gaussian Distribution of Clustered Knowledge [43], Multilayer Perceptron, Naive Bayes, Decision tree [44,47], ZeroR and OneR [44]. The multilayer perceptron seems to be a good supervised option according to Kerdegari et al. [44], although there is no standardized technique that is widely accepted by the scientific community.

The average number of subjects involved in the tests is about 17, which is significantly higher than in context-aware systems (previous section). This indicates a higher reliability of this technology but still insufficient; only 6 of the works involve older people in the ADL study $[9,33,35,37,40,45]$, while the rest use simulated data 
Table 3 Comparison of acceleration based fall detectors using external accelerometers

\begin{tabular}{|c|c|c|c|c|c|c|c|c|c|}
\hline Article & Year & Basis & Detection technique & Fall types & Subjects & $\begin{array}{l}\text { Declared } \\
\text { perform }\end{array}$ & Position & $\begin{array}{l}\text { Elders } \\
\text { Yes/No }\end{array}$ & Comments \\
\hline \multirow[t]{2}{*}{ Lindeman et al. [33] } & \multirow[t]{2}{*}{2005} & \multirow[t]{2}{*}{$\begin{array}{l}\text { A fall detector } \\
\text { placed at head } \\
\text { level }\end{array}$} & \multirow{2}{*}{$\begin{array}{l}\text { TBM considering the spatial } \\
\text { direction of the head, the } \\
\text { velocity right before the initial } \\
\text { contact with the ground and the } \\
\text { impact }\end{array}$} & $\begin{array}{l}\text { Falls to the front, side } \\
\text { with a } 90^{\circ} \text { turn, back, } \\
\text { back with hip flexion. }\end{array}$ & \multirow[t]{2}{*}{$\begin{array}{c}\text { A young volunteer } \\
\text { and an elderly woman } \\
\text { (83 years) }\end{array}$} & \multirow{2}{*}{$\begin{array}{l}\text { High } \\
\text { sensitivity } \\
\text { and } \\
\text { specificity }\end{array}$} & \multirow[t]{2}{*}{ Ear } & \multirow[t]{2}{*}{ Yes } & \multirow{2}{*}{$\begin{array}{c}\text { Accelerometers were } \\
\text { integrated into a hearing-aid } \\
\text { housing, which was fixed } \\
\text { behind the ear }\end{array}$} \\
\hline & & & & $\begin{array}{l}\text { Falls backwards against } \\
\text { a wall, while picking up } \\
\text { an object and collapse. }\end{array}$ & & & & & \\
\hline Chen et al. [34] & 2005 & $\begin{array}{l}\text { Detect the } \\
\text { occurrence of a } \\
\text { fall and the } \\
\text { location of the } \\
\text { victim }\end{array}$ & $\begin{array}{l}\text { TBM considering the impact and } \\
\text { the change in orientation }\end{array}$ & $\begin{array}{l}\text { Backward and sideways } \\
\text { falls }\end{array}$ & 2 subjects & $\begin{array}{l}\text { The } \\
\text { acceleration } \\
\text { for ADL is } \\
\text { much less } \\
\text { than the } \\
\text { observed } \\
\text { from falling }\end{array}$ & Waist & No & $\begin{array}{l}\text { The final orientation of the } \\
\text { wearer is considered }\end{array}$ \\
\hline \multirow[t]{2}{*}{ Zhang et al. [45] } & \multirow[t]{2}{*}{2006} & \multirow{2}{*}{$\begin{array}{l}\text { Fall detection } \\
\text { using machine } \\
\text { learning } \\
\text { strategies }\end{array}$} & \multirow{2}{*}{$\begin{array}{l}\text { MLM. 1) Extraction of temporal } \\
\text { and magnitude features from the } \\
\text { acceleration signal, 2) One-class } \\
\text { Support Vector Machine classifier }\end{array}$} & Soft fall & \multirow{2}{*}{$\begin{array}{l}12 \text { subjects ( } 8 \text { males, } \\
4 \text { females, ages } 10-70 \text { ) }\end{array}$} & \multirow{2}{*}{$\begin{array}{l}\text { Accuracy } \\
96,7 \%\end{array}$} & \multirow[t]{2}{*}{ Waist } & \multirow[t]{2}{*}{ Yes } & \multirow{2}{*}{$\begin{array}{l}\text { To the best of our } \\
\text { knowledge, this study is the } \\
\text { first in using machine } \\
\text { learning techniques }\end{array}$} \\
\hline & & & & $\begin{array}{l}\text { Hard fall in the ground, } \\
\text { stairs and slopes (using } \\
\text { a mannequin) }\end{array}$ & & & & & \\
\hline \multirow[t]{4}{*}{ Bourke et al. [35] } & \multirow[t]{4}{*}{2007} & \multirow{4}{*}{$\begin{array}{l}\text { Investigation into } \\
\text { the ability to } \\
\text { discriminate } \\
\text { between falls and } \\
\text { ADL }\end{array}$} & \multirow{4}{*}{$\begin{array}{l}\text { TBM using information from the } \\
\text { impact }\end{array}$} & \multirow{4}{*}{$\begin{array}{l}\text { Forward falls, backward } \\
\text { falls and lateral falls left } \\
\text { and right, performed } \\
\text { with legs straight and } \\
\text { flexed }\end{array}$} & \multirow{2}{*}{$\begin{array}{l}10 \text { subjects } \\
\text { (ages } 21-29 \text { ) }\end{array}$} & Trunk & \multirow{4}{*}{$\begin{array}{l}\text { Trunk, } \\
\text { thigh }\end{array}$} & \multirow[t]{4}{*}{ Yes } & \multirow{4}{*}{$\begin{array}{l}\text { The trunk appears to be the } \\
\text { optimum location for a fall } \\
\text { sensor }\end{array}$} \\
\hline & & & & & & SP:100\% & & & \\
\hline & & & & & 10 community-dwelling & Thigh & & & \\
\hline & & & & & $\begin{array}{l}\text { elderly subjects (3 temales, } \\
7 \text { males, ages 70-83) }\end{array}$ & SP: $83.3 \%$ & & & \\
\hline \multirow[t]{2}{*}{ Doukas et al. [46] } & \multirow[t]{2}{*}{2007} & \multirow{2}{*}{$\begin{array}{l}\text { Accelerometers } \\
\text { transmit patient } \\
\text { movement data } \\
\text { wirelessly to the } \\
\text { monitoring unit }\end{array}$} & \multirow{2}{*}{$\begin{array}{l}\text { MLM. The acceleration in the } \\
\text { three axis is classified using } \\
\text { Support Vector Machine }\end{array}$} & \multirow[t]{2}{*}{ Not specified } & \multirow[t]{2}{*}{1 subject } & SE: $98.2 \%$ & \multirow[t]{2}{*}{ Foot } & \multirow[t]{2}{*}{ No } & \multirow{2}{*}{$\begin{array}{l}\text { If a fall is suspected it also } \\
\text { transmits video images to } \\
\text { remote monitoring units }\end{array}$} \\
\hline & & & & & & SP: $96.7 \%$ & & & \\
\hline
\end{tabular}


Table 3 Comparison of acceleration based fall detectors using external accelerometers (Continued)

\begin{tabular}{|c|c|c|c|c|c|c|c|c|c|}
\hline \multirow[t]{3}{*}{ Kangas et al. [36] } & \multirow[t]{3}{*}{2008} & \multirow{3}{*}{$\begin{array}{l}\text { Comparison of } 3 \\
\text { low-complexity } \\
\text { algorithms }\end{array}$} & \multirow{3}{*}{$\begin{array}{c}\text { TBM considering the start of the } \\
\text { fall, the velocity, the impact and } \\
\text { the lying posture }\end{array}$} & \multirow{3}{*}{$\begin{array}{l}\text { Forward, backward, and } \\
\text { lateral falls }\end{array}$} & \multirow{3}{*}{$\begin{array}{l}3 \text { volunteers ( } 1 \text { female, } \\
2 \text { males; ages } 38,42,48)\end{array}$} & Waist & \multirow{3}{*}{$\begin{array}{l}\text { Wrist, } \\
\text { head, } \\
\text { waist }\end{array}$} & \multirow[t]{3}{*}{ No } & \multirow{3}{*}{$\begin{array}{l}\text { Waist worn accelerometer } \\
\text { might be optimal for fall } \\
\text { detection considering the fall } \\
\text { associated impact and the } \\
\text { posture after the fall }\end{array}$} \\
\hline & & & & & & SP: $100 \%$ & & & \\
\hline & & & & & & SE: $98 \%$ & & & \\
\hline \multirow[t]{2}{*}{ Kangas et al. [37] } & \multirow[t]{2}{*}{2009} & \multirow{2}{*}{$\begin{array}{l}\text { To validate the } \\
\text { data collection } \\
\text { of a new fall } \\
\text { detector } \\
\text { prototype }\end{array}$} & \multirow{2}{*}{$\begin{array}{l}\text { TBM considering two or more of } \\
\text { the following phases of a fall } \\
\text { event: start of the fall, falling } \\
\text { velocity, fall impact, and posture } \\
\text { after the fall }\end{array}$} & \multirow{2}{*}{$\begin{array}{l}\text { Syncope, tripping, } \\
\text { sitting on empty air, } \\
\text { slipping, lateral fall, } \\
\text { rolling out of bed }\end{array}$} & \multirow{2}{*}{$\begin{array}{c}20 \text { subjects } \\
\text { (40-65 years old), } \\
21 \text { voluntary older } \\
\text { people (58-98 years old) }\end{array}$} & SP: $100 \%$ & \multirow[t]{2}{*}{ Waist } & \multirow[t]{2}{*}{ Yes } & \multirow{2}{*}{$\begin{array}{l}\text { Middle-aged persons could } \\
\text { be considered to mimic the } \\
\text { fall events of older people } \\
\text { more adequately than young } \\
\text { subjects would }\end{array}$} \\
\hline & & & & & & SE: $97.5 \%$ & & & \\
\hline \multirow[t]{2}{*}{ Li et al. [38] } & \multirow[t]{2}{*}{2009} & \multirow{2}{*}{$\begin{array}{l}\text { Fall detection } \\
\text { system using } \\
\text { both } \\
\text { accelerometers } \\
\text { and gyroscopes }\end{array}$} & \multirow{2}{*}{$\begin{array}{l}\text { TBM analyzing the intensity of } \\
\text { the activity, the posture and } \\
\text { whether the transition to a lying } \\
\text { posture was unintentional or not }\end{array}$} & \multirow{2}{*}{$\begin{array}{l}\text { Forward, backward, } \\
\text { sideways and vertical } \\
\text { falls. Falling on stairs } \\
\text { and fall against walls } \\
\text { ending with a sitting } \\
\text { position }\end{array}$} & \multirow{2}{*}{$\begin{array}{l}3 \text { male subjects } \\
\text { (age } 20)\end{array}$} & SP: $92 \%$ & \multirow{2}{*}{$\begin{array}{l}\text { Chest, } \\
\text { thigh }\end{array}$} & \multirow[t]{2}{*}{ No } & \multirow{2}{*}{$\begin{array}{l}\text { Human activities are divided } \\
\text { into static postures and } \\
\text { dynamic transitions }\end{array}$} \\
\hline & & & & & & SE: $91 \%$ & & & \\
\hline \multirow[t]{2}{*}{ Shan et al. [42] } & \multirow[t]{2}{*}{2010} & \multirow{2}{*}{$\begin{array}{l}\text { Investigation of a } \\
\text { pre-impact fall } \\
\text { detector }\end{array}$} & \multirow{2}{*}{$\begin{array}{l}\text { MLM 1) A discriminant analysis is } \\
\text { applied to time-domain statistical } \\
\text { characteristics to select the } \\
\text { features, 2) Support Vector } \\
\text { Machine is used for fall } \\
\text { recognition }\end{array}$} & \multirow{2}{*}{$\begin{array}{l}\text { Forward falls, backward } \\
\text { falls, lateral falls left and } \\
\text { right (subjects were } \\
\text { instructed to keep their } \\
\text { postures for about } \\
2 \text { seconds after the fall) }\end{array}$} & \multirow{2}{*}{$\begin{array}{l}5 \text { male subjects } \\
\text { (ages } 21-28 \text { ) }\end{array}$} & SP: $100 \%$ & \multirow[t]{2}{*}{ Waist } & \multirow[t]{2}{*}{ No } & \multirow{2}{*}{$\begin{array}{l}\text { Impending falls are detected } \\
\text { in their descending phase } \\
\text { before the body hits the } \\
\text { ground }\end{array}$} \\
\hline & & & & & & SE: $100 \%$ & & & \\
\hline \multirow[t]{4}{*}{ Bianchi et al. [39] } & \multirow[t]{4}{*}{2010} & Augmentation of & TBM considering the impact, the & Forward, backward and & 20 subjects ( 12 male, & SP: $96.5 \%$ & Waist & No & A system based on a \\
\hline & & $\begin{array}{l}\text { accelerometer- } \\
\text { based systems }\end{array}$ & $\begin{array}{l}\text { postural orientation, and the } \\
\text { change in altitude associated }\end{array}$ & $\begin{array}{l}\text { lateral talls (endıng lyıng, } \\
\text { with recovery with }\end{array}$ & 8 temale; $n$ & SE: 97.5\% & & & \\
\hline & & $\begin{array}{l}\text { with a barometric } \\
\text { pressure sensor }\end{array}$ & with a fall & $\begin{array}{l}\text { attempt to break the } \\
\text { fall) }\end{array}$ & $\begin{array}{c}5 \text { subjects ( } 2 \text { male, } \\
3 \text { female; mean age: } 24)\end{array}$ & & & & $\begin{array}{l}\text { accelerometry-based } \\
\text { technique. The acceleration }\end{array}$ \\
\hline & & & & $\begin{array}{l}\text { Resting against a wall, } \\
\text { then sliding vertically } \\
\text { down to the end in the }\end{array}$ & $\begin{array}{l}5 \text { subjects ( } 5 \text { male, } \\
\text { mean age: } 26.4)\end{array}$ & & & & $\begin{array}{l}\text { and air pressure data are } \\
\text { recorded using a wearable } \\
\text { device }\end{array}$ \\
\hline
\end{tabular}


Table 3 Comparison of acceleration based fall detectors using external accelerometers (Continued)

\begin{tabular}{|c|c|c|c|c|c|c|c|c|c|}
\hline \multirow[t]{2}{*}{ Bourke et al. [40] } & \multirow[t]{2}{*}{2010} & \multirow{2}{*}{$\begin{array}{l}\text { It compares } \\
\text { novel fall- } \\
\text { detection } \\
\text { algorithms of } \\
\text { varying } \\
\text { complexity }\end{array}$} & \multirow[t]{2}{*}{$\begin{array}{l}\text { TBM considering the fall impact, } \\
\text { the velocity and the posture }\end{array}$} & \multirow{2}{*}{$\begin{array}{l}\text { Forward falls, backward } \\
\text { falls, lateral falls left and } \\
\text { right all performed with } \\
\text { both legs straight and } \\
\text { with knees relaxed }\end{array}$} & $\begin{array}{l}10 \text { male subjects } \\
\text { (age } 24-35 \text { ) }\end{array}$ & SP: $100 \%$ & \multirow[t]{2}{*}{ Waist } & \multirow[t]{2}{*}{ Yes } & \multirow{2}{*}{$\begin{array}{l}\text { The algorithms were tested } \\
\text { against } A D L \text { performed by } \\
\text { elderly subjects }\end{array}$} \\
\hline & & & & & $\begin{array}{l}10 \text { older subjects } \\
(6 \text { male, } 4 \text { female, } \\
\text { age } 73-90)\end{array}$ & SE: $94.6 \%$ & & & \\
\hline Lai et al. [41] & 2011 & $\begin{array}{l}\text { Several } \\
\text { acceleration } \\
\text { sensors for joint } \\
\text { sensing fall } \\
\text { events }\end{array}$ & $\begin{array}{l}\text { TBM to differentiate dynamic/ } \\
\text { static states using the } \\
\text { acceleration of the three axis }\end{array}$ & $\begin{array}{l}\text { Forward, backward, } \\
\text { rightward or leftward } \\
\text { falls }\end{array}$ & 16 subjects & $\begin{array}{l}\text { Accuracy } \\
92.92 \%\end{array}$ & $\begin{array}{l}\text { Neck, } \\
\text { hand, } \\
\text { waist, } \\
\text { foot }\end{array}$ & No & $\begin{array}{l}\text { After a fall accident occurs, } \\
\text { the system determines the } \\
\text { level of injury }\end{array}$ \\
\hline \multirow[t]{4}{*}{ Bagala et al. [9] } & \multirow[t]{4}{*}{2012} & \multirow{4}{*}{$\begin{array}{l}\text { Benchmark the } \\
\text { performance of } \\
\text { published fall- } \\
\text { detection } \\
\text { methods when } \\
\text { they are applied } \\
\text { to real-world falls }\end{array}$} & \multirow{4}{*}{$\begin{array}{c}\text { TBM including, among others, } \\
\text { the algorithms published in } \\
{[35,36]}\end{array}$} & \multirow{4}{*}{$\begin{array}{l}\text { Real-world falls: indoor/ } \\
\text { outdoor, forward } \\
\text { /backward /sideward, } \\
\text { impact against the floor } \\
\text { /wall or locker before } \\
\text { hitting the floor / sofa } \\
\text { or bed/ desk }\end{array}$} & $\begin{array}{l}9 \text { subjects (7 women, } \\
2 \text { men, age: } 66.4 \pm 6.2)\end{array}$ & $\begin{array}{l}\text { Average } 13 \\
\text { algorithms }\end{array}$ & \multirow[t]{4}{*}{$\begin{array}{l}\text { Lower } \\
\text { back }\end{array}$} & \multirow[t]{4}{*}{ Yes } & \multirow{4}{*}{$\begin{array}{l}\text { Algorithms that were } \\
\text { successful at detecting } \\
\text { simulated falls did not } \\
\text { perform well when } \\
\text { attempting to detect real- } \\
\text { world falls }\end{array}$} \\
\hline & & & & & 15 subjects & $\begin{array}{l}\text { SP: } 83.0 \% \\
\pm 30.3 \%\end{array}$ & & & \\
\hline & & & & & 29 subjects & SE: $57.0 \%$ & & & \\
\hline & & & & & 1 subject & $\pm 27.3 \%$ & & & \\
\hline \multirow[t]{2}{*}{ Yuwono et al. [43] } & \multirow[t]{2}{*}{2012} & \multirow{2}{*}{$\begin{array}{l}\text { Use of a } \\
\text { sophisticated fall } \\
\text { detection } \\
\text { method }\end{array}$} & \multirow{2}{*}{$\begin{array}{l}\text { MLM. 1) Discrete wavelet } \\
\text { transform, 2) Associate a cluster } \\
\text { to the input feature vector; fuse } \\
\text { cluster information with input, 3) } \\
\text { Combined classification (vote } \\
\text { majority): Multilayer Perceptron } \\
\text { and Augmented Radial Basis } \\
\text { Function }\end{array}$} & \multirow[t]{2}{*}{ Not specified } & \multirow{2}{*}{$\begin{array}{l}8 \text { individuals } \\
\text { (age 19-28) }\end{array}$} & SP: $99.6 \%$ & \multirow[t]{2}{*}{ Waist } & \multirow[t]{2}{*}{ No } & \multirow{2}{*}{$\begin{array}{l}\text { Training and clustering are } \\
\text { done off-line. Clustering is } \\
\text { done using Regrouping } \\
\text { particle swarm optimization }\end{array}$} \\
\hline & & & & & & SE: $98.6 \%$ & & & \\
\hline \multirow[t]{3}{*}{ Kerdegari et al. [44] } & \multirow[t]{3}{*}{2012} & \multirow{3}{*}{$\begin{array}{l}\text { Investigation of } \\
\text { the performance } \\
\text { of different } \\
\text { classification } \\
\text { algorithms }\end{array}$} & \multirow{3}{*}{$\begin{array}{l}\text { MLM. Input is pre-processed } \\
\text { using windowing techniques. } \\
\text { Features include acceleration, } \\
\text { angular velocity, velocity, } \\
\text { position and time domain } \\
\text { features: maximum, minimum, } \\
\text { mean, range, variance and } \\
\text { standard deviation. Several } \\
\text { methods are compared. }\end{array}$} & $\begin{array}{l}\text { With flexed knees: } \\
\text { forward, backward, } \\
\text { sideways falls }\end{array}$ & \multirow[t]{3}{*}{$\begin{array}{c}50 \text { volunteers ( } 18 \text { male, } \\
32 \text { female, average } \\
\text { age } 32 \text { ) }\end{array}$} & SE: $90.15 \%$ & \multirow[t]{3}{*}{ Waist } & \multirow[t]{3}{*}{ No } & \multirow{2}{*}{$\begin{array}{c}\text { Multilayer Perceptron, Naive } \\
\text { Bayes, Decision tree, Support } \\
\text { Vector Machine, ZeroR and } \\
\text { OneR algorithms are } \\
\text { compared. }\end{array}$} \\
\hline & & & & $\begin{array}{l}\text { Base on wall: backward, } \\
\text { sideways falls }\end{array}$ & & & & & \\
\hline & & & & $\begin{array}{l}\text { Backward falls sitting } \\
\text { on empty, turning left } \\
\text { and right }\end{array}$ & & & & & $\begin{array}{l}\text { Results show that the } \\
\text { Multilayer Perceptron } \\
\text { algorithm is the best option }\end{array}$ \\
\hline
\end{tabular}




\section{Table 3 Comparison of acceleration based fall detectors using external accelerometers (Continued)}

\begin{tabular}{|c|c|c|c|c|c|c|c|c|c|}
\hline \multirow[t]{2}{*}{ Cheng et al. [47] } & \multirow[t]{2}{*}{2013} & \multirow{2}{*}{$\begin{array}{l}\text { Daily activity } \\
\text { monitoring and } \\
\text { fall detection }\end{array}$} & \multirow{2}{*}{$\begin{array}{l}\text { TBM using a decision tree: 1) A } \\
\text { decision tree is applied to the } \\
\text { angles of all the body postures } \\
\text { to recognize posture transitions, } \\
\text { 2) the impact magnitude is } \\
\text { thresholded to detect the falls }\end{array}$} & \multirow{2}{*}{$\begin{array}{l}\text { Four types of falls: from } \\
\text { standing to face-up } \\
\text { lying, face-down lying, } \\
\text { left-side lying, and } \\
\text { right-side lying }\end{array}$} & \multirow{2}{*}{$\begin{array}{l}10 \text { subjects ( } 6 \text { males, } \\
4 \text { females, age } 22-26)\end{array}$} & SE: $95.33 \%$ & Chest & \multirow[t]{2}{*}{ No } & \multirow{2}{*}{$\begin{array}{l}\text { Dynamic gait activities are } \\
\text { also identified using Hidden } \\
\text { Markov Models. Surface } \\
\text { electromyography signals are } \\
\text { combined with the } \\
\text { acceleration signals. }\end{array}$} \\
\hline & & & & & & SP: $97.66 \%$ & Thigh & & \\
\hline
\end{tabular}

TBM: Threshold Based Method, MLM: Machine Learning Method. 
from young volunteers. As in the previous section, longer real-world tests with target users would be required.

Nearly all the studies concur that the broader categories of typical fall events are forward, backward and sideways, although some of them extend these categories to cover a large number of fall situations [33,38,39]. Regarding the position of the accelerometer, the placement site at the waist seems to be optimal for fall detection. Waist attached accelerometers are located near the body's centre of gravity, providing reliable information on subject body movements [36].

As in the previous category, the declared performance is very high, but the fact is that there is little use of these devices in daily geriatric practice and no significant industrial deployment of fall detectors due mainly to the significant number of false alarms, resulting in inappropriate alerts [8]. The declared results are valid for laboratory environments with limited data or under restricted conditions, but in real-world scenarios there are lots of uncontrolled factors that lead to a dramatic loss in performance [9]. Therefore, studies should incorporate longer tests and include indicators closer to a real-world usage, for example the number of false alarms per day, which may provide target users with a more realistic idea of the true performance of the system.

\section{Smartphone built-in accelerometer}

Today's smartphones come with a rich set of embedded sensors, such as an accelerometer, digital compass, gyroscope, GPS, microphone, and camera [48]. Several researchers are currently taking advantage of this fact to develop smartphone based fall detectors. Table 4 summarizes some relevant works in this field.

Low-complexity algorithms based on thresholding are used in most of the studies [49-53], and only few go further and adopt machine learning strategies [54,55]. They use Support Vector Machines, Sparse Multinomial Logistic Regression, Naïve Bayes, K-Nearest Neighbors, Decision Trees [54] and Multi-layer Neural Networks [55].

The types of falls considered and the number of subjects involved in the studies are similar to those of the previous section. Regarding the position of the phone, the waist is still the preferred part of the body [52,55], although there is an emerging trend towards the thigh, coinciding with the location of the pocket [49-51,53].

Some of these studies [49] have resulted in real fall detection applications that are available for download in Google Play [56]. This site offers another source of information. Thus, a search has been conducted in this repository including either "fall detector" or "fall detection" as the keywords. As a result, a total of 9 applications were obtained, of which 7 were for seniors. To quote some statistics, 3 of them reported between 1000 and 5000 downloads, while the rest had less than 500. Although these numbers indicate a certain level of interest, they are still far from the number of potential users. Focusing on the app rating, we found that an average of only 6 people have given their opinions on them. This is a symptom that people using these apps do not seem to be enthusiastic about them.

The number of published studies based on smartphones is still low in comparison with the previous categories, and none of them involve older people to evaluate the detector. Therefore, studies still need to incorporate a more exhaustive evaluation. These are signs that we are facing an emerging field. 
Table 4 Smartphone based fall detectors

\begin{tabular}{|c|c|c|c|c|c|c|c|c|c|}
\hline Article & Year & Basis & Detection technique & Fall types & Study design & $\begin{array}{l}\text { Declared } \\
\text { perform }\end{array}$ & Position & $\begin{array}{l}\text { Elders } \\
\text { Yes/No }\end{array}$ & Comments \\
\hline \multirow[t]{2}{*}{ Sposaro et al. [49] } & \multirow[t]{2}{*}{2009} & \multirow{2}{*}{$\begin{array}{l}\text { Alert system for fall } \\
\text { detection using smart } \\
\text { phones }\end{array}$} & \multirow{2}{*}{$\begin{array}{l}\text { TBM considering the } \\
\text { impact, the difference in } \\
\text { position before and after } \\
\text { the fall and whether the } \\
\text { fallen patient is able to } \\
\text { regain the upright } \\
\text { position }\end{array}$} & \multirow[t]{2}{*}{ Not included } & \multirow[t]{2}{*}{ Not included } & \multirow[t]{2}{*}{ Not included } & \multirow[t]{2}{*}{$\begin{array}{l}\text { Thigh } \\
\text { (pocket) }\end{array}$} & \multirow[t]{2}{*}{ No } & $\begin{array}{l}\text { First documented mobile } \\
\text { phone-based fall detector }\end{array}$ \\
\hline & & & & & & & & & $\begin{array}{l}\text { The existence of a lying } \\
\text { period after falling is checked }\end{array}$ \\
\hline Dai et al. [50] & 2010 & $\begin{array}{l}\text { Mobile phones as a } \\
\text { platform for } \\
\text { developing fall } \\
\text { detection systems }\end{array}$ & $\begin{array}{l}\text { TBM considering the } \\
\text { impact, the wearer's } \\
\text { orientation and the } \\
\text { common step mechanics } \\
\text { during falling }\end{array}$ & $\begin{array}{c}\text { Forward, lateral and } \\
\text { backward falls with } \\
\text { different speeds (fast } \\
\text { and slow) and in } \\
\text { different environment } \\
\text { (living room, kitchen, } \\
\text { etc.) }\end{array}$ & $\begin{array}{l}15 \text { participants } \\
\text { from } 20 \text { to } 30 \text { years old } \\
\text { (2 females, } 13 \text { males) }\end{array}$ & $\begin{array}{l}\text { Good detection } \\
\text { performance }\end{array}$ & $\begin{array}{l}\text { Chest, } \\
\text { waist, } \\
\text { thigh }\end{array}$ & No & $\begin{array}{c}\text { A detection algorithm with } \\
\text { an external accessory is } \\
\text { included }\end{array}$ \\
\hline Lopes et al. [51] & 2011 & $\begin{array}{l}\text { Application to detect } \\
\text { and report falls, } \\
\text { sending SMS or } \\
\text { locating the phone }\end{array}$ & $\begin{array}{l}\text { TBM considering the } \\
\text { impact }\end{array}$ & $\begin{array}{l}\text { Fall into bed, forward } \\
\text { fall, backward fall, fall } \\
\text { in slow motion }\end{array}$ & Not specified & Not specified & Thigh & No & $\begin{array}{c}\text { Five scenarios to validate the } \\
\text { detector are presented. Each } \\
\text { scenario includes ADL and } \\
\text { falls. }\end{array}$ \\
\hline Albert et al. [54] & 2012 & $\begin{array}{l}\text { Demonstrate } \\
\text { techniques to not } \\
\text { only reliably detect a } \\
\text { fall but also to } \\
\text { automatically classify } \\
\text { the type }\end{array}$ & $\begin{array}{l}\text { MLMs using a large time- } \\
\text { series feature set from the } \\
\text { acceleration signal. }\end{array}$ & $\begin{array}{l}\text { Left and right lateral, } \\
\text { forward trips, and } \\
\text { backward slips }\end{array}$ & $\begin{array}{l}15 \text { subjects (8 females, } \\
7 \text { males, ages } 22-50 \text { ) }\end{array}$ & $\begin{array}{l}\text { Across an } \\
\text { average week of } \\
\text { everyday } \\
\text { movements } \\
\text { there are } 2-3 \\
\text { non-falls } \\
\text { misclassified as } \\
\text { falls }\end{array}$ & Back & No & $\begin{array}{l}\text { Five machine learning } \\
\text { classifiers are compared: } \\
\text { Support vector machines, } \\
\text { Sparse multinomial logistic } \\
\text { regression, Naïve Bayes, K- } \\
\text { nearest neighbours, and } \\
\text { Decision trees }\end{array}$ \\
\hline \multirow[t]{2}{*}{ Lee et al. [52] } & \multirow[t]{2}{*}{2012} & \multirow{2}{*}{$\begin{array}{l}\text { Study the sensitivity } \\
\text { and specificity of fall } \\
\text { detection using } \\
\text { mobile phone } \\
\text { technology }\end{array}$} & \multirow{2}{*}{$\begin{array}{l}\text { TBM considering the } \\
\text { impact }\end{array}$} & \multirow{2}{*}{$\begin{array}{c}\text { Forwards, backwards, } \\
\text { lateral left and lateral } \\
\text { right }\end{array}$} & \multirow{2}{*}{$\begin{array}{l}18 \text { subjects ( } 12 \text { males, } \\
6 \text { females, ages } 29 \pm 8.7 \text { ) }\end{array}$} & SP: $81 \%$ & \multirow[t]{2}{*}{ Waist } & \multirow[t]{2}{*}{ No } & \multirow{2}{*}{$\begin{array}{l}\text { The motion signals acquired } \\
\text { by the phone are compared } \\
\text { with those recorded by an } \\
\text { independent accelerometer }\end{array}$} \\
\hline & & & & & & SE: $77 \%$ & & & \\
\hline
\end{tabular}


Table 4 Smartphone based fall detectors (Continued)

\begin{tabular}{|c|c|c|c|c|c|c|c|c|c|}
\hline \multirow[t]{2}{*}{ Fang et al. [53] } & \multirow[t]{2}{*}{2012} & \multirow{2}{*}{$\begin{array}{l}\text { Fall detection } \\
\text { prototype for the } \\
\text { Android-based } \\
\text { platform }\end{array}$} & \multirow{2}{*}{$\begin{array}{l}\text { TBM considering the } \\
\text { impact and the patient's } \\
\text { orientation }\end{array}$} & \multirow[t]{2}{*}{ Not specified } & \multirow[t]{2}{*}{4 subjects } & SP: $73.78 \%$ & \multirow{2}{*}{$\begin{array}{l}\text { Chest, } \\
\text { waist } \\
\text { thigh }\end{array}$} & \multirow[t]{2}{*}{ No } & \multirow{2}{*}{$\begin{array}{c}\text { Different phone-attached } \\
\text { locations are analysed. The } \\
\text { chest seems to be the best } \\
\text { place. }\end{array}$} \\
\hline & & & & & & SE: $77.22 \%$ & & & \\
\hline \multirow[t]{2}{*}{ Abbate et al. [55] } & \multirow[t]{2}{*}{2012} & \multirow{2}{*}{$\begin{array}{l}\text { A system to monitor } \\
\text { the movements of } \\
\text { patients, recognize a } \\
\text { fall, and automatically } \\
\text { send a request for } \\
\text { help to the caregivers }\end{array}$} & \multirow{2}{*}{$\begin{array}{l}\text { MLM Eight acceleration } \\
\text { properties of fall-like } \\
\text { events are classified using } \\
\text { multi-layer feed-forward } \\
\text { neural network }\end{array}$} & \multirow{2}{*}{$\begin{array}{l}\text { Forward fall, backward } \\
\text { fall, and faint (normal } \\
\text { speed and slow } \\
\text { motion) }\end{array}$} & \multirow{2}{*}{$\begin{array}{l}7 \text { volunteers ( } 5 \text { male, } \\
2 \text { female, ages } 20-67 \text { ) }\end{array}$} & SP: 100\% & \multirow[t]{2}{*}{ Waist } & \multirow[t]{2}{*}{ No } & \multirow{2}{*}{$\begin{array}{c}\text { The proposed approach is } \\
\text { compared with the } \\
\text { techniques described in } \\
{[35,36,49,66]}\end{array}$} \\
\hline & & & & & & SE: $100 \%$ & & & \\
\hline
\end{tabular}




\section{Discussion}

\section{Trends, challenges and issues}

Based on the extensive literature search, challenges, issues, and trends in fall detection systems have been identified. This section presents the most relevant ones.

\section{Trends}

We start by describing the current and future trends in fall detection systems.

\section{Trend 1: Vision and smartphone-based detectors}

Context-aware techniques appeared over a decade ago and the number of studies is still increasing after a drop some years ago (Figure 1), most of them being video-based systems. It is unfortunate that the algorithmic details of these systems do not seem to converge. Computer Vision approaches are very complex and it is difficult to obtain a system that can work under real life conditions. On the other hand, the use of body-worn accelerometers has stagnated in the last years, but this trend is offset by the increase in the number of smartphone-based studies. In fact, this is still a novel technology: the first study using smartphones appeared in 2009 [49] and since then the research in this field has grown steadily. These are signs that we are facing an emerging trend, which may be explained by the advantages offered by smartphones. As self-contained devices, they present a mature hardware and software environment for developing pervasive fall detection systems [50]. They have built-in communication protocols that allow simple data logging to the device and wireless transmission. Price is also significantly reduced due to high production volume [54,57].

\section{Trend 2: Machine learning approach}

There are two main approaches to detect falls using acceleration signals: thresholding techniques and machine learning methods. Applications based on the first approach

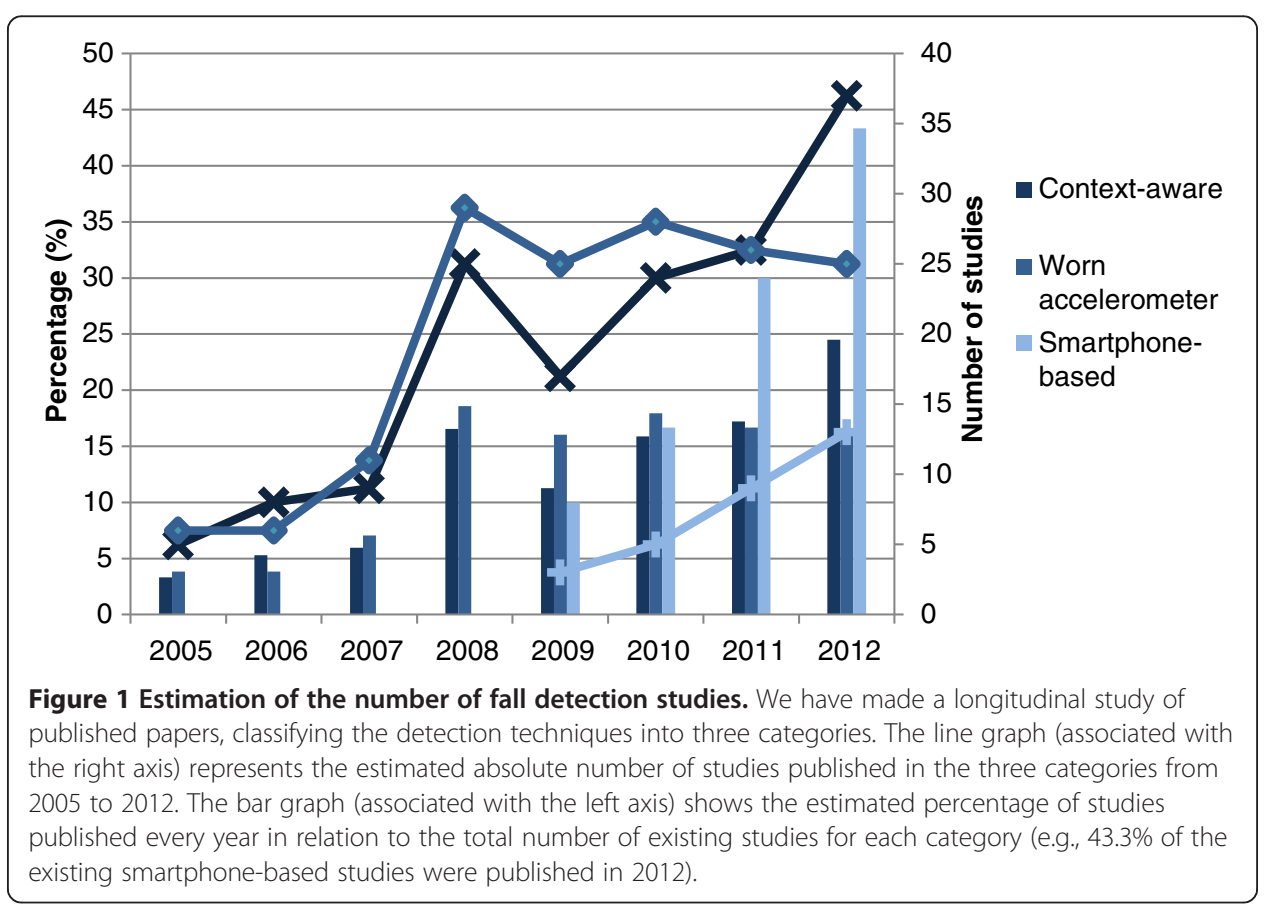


are simple to implement and their computational work is minimal. They are able to detect when a fall occurs. However, the rate of false positives is a significant issue [54]. The machine learning approach is more sophisticated and leads to better detection rates. Nevertheless, there have been documented difficulties with implementing these techniques (for example: requirement of high mathematical skills, use of more computation resources, etc.), although they are currently the prevailing trend, since thresholding methods proved to be ineffective [9]. In addition, no method has been widely accepted and each paper presents a different approach among the variety of machine learning algorithms.

\section{Challenges}

The design of fall detectors faces some major challenges described in this section.

\section{Challenge 1: Performance under real-life conditions}

Fall detectors need to be as accurate and reliable as possible. A robust fall detection system should exhibit both high sensitivity and specificity. This is sometimes reached in experimental environments, but when applied to a real situation, the detection rate decreases [8]. These devices are designed and tested under controlled conditions, for example they use data from falls and ADL of young people simulated at the discretion of each author due to the lack of a standardized procedure or a public database for comparison. Furthermore, it is worth pointing out that fall detectors are aimed at older people, so they should also be involved in their development. Only few studies incorporate data from older people $[9,33,35,37,40,45]$, although their participation is limited to perform a set of simulated activities of daily living for a few minutes or hours. That is not enough to assess the system performance in a real situation. Users should wear the devices for longer periods (at least months). Some studies have worked in this direction $[4,9]$, resulting in a significant number of false activations, among other concerns.

\section{Challenge 2: Usability}

Smartphone-based fall detectors are attractive because of the widespread use of phones, even among the older population [58]. However, the majority of the studies referenced in Table 4 placed them in a standardized position. This allowed highly stereotypical measurements that aided accuracy ratings, but made the results less applicable to the way people carry their smartphones every day (for example: in pockets or handbags) [54]. Future smartphone-based detectors should not limit the placement of the device to a single part of the body (waist, wrist, chest, etc.). Smartphones should be used in a normal way, with no restrictions regarding their position or functionalities. This may lead to lower detection rates.

\section{Challenge 3: Acceptance}

Little is published about the practicality and acceptability of the technology. Elders' acceptance poses a major problem since they may not be familiar with electronic devices. To overcome this challenge, the way the system operates is essential [59]. The detector should activate and operate automatically, without user intervention. Vision systems, like other non intrusive methods, are very good in this sense. However, some wearable devices like smartphones have other advantages that can help to improve the acceptance of fall detectors. They can operate both indoors and outdoors and 
integrate not only fall detection but also other healthcare applications in the same device. In this way, the traditional reluctance to carry different devices, each one targeting a specific function, would be overcome. However, the use of smartphones by older people is not without difficulty: these devices, as they were conceived, represent a major usability barrier for them. Proof of this is the absence of rating in the existing fall detection applications, which is a symptom of little real use. In this sense, potential solutions to improve the usability and accessibility of smartphones are needed. Nevertheless, as a result of a study still in progress we have found that fall detectors were highly valued by the elderly, who showed a positive attitude towards smartphonebased solutions after carrying out a practical demonstration of several assistive technologies. This conclusion agrees with the work of Plaza et al. [60], who reviewed mobile applications for older people and found that they are most frequently related to two domains: "Health - wellness - home care" and "Safety - security - mobility".

\section{Issues}

This section describes the most significant issues which could hinder the system performance.

\section{Issue 1: Smartphone limitations}

The trend towards smartphone-based detectors poses some problems. Firstly, smartphones are not devices initially intended for fall detection or any other safety critical application [49]. There might be difficulties with real-time operations, the sensing architecture, the stability of the accelerometer's sampling frequency, the specific features of the operating system, etc. Indeed, the same fall detector might behave slightly differently depending on the smartphone model in which it is installed. This possibility should be taken into account in a real-world scenario. Secondly, smartphones cannot be overloaded with continuous sensing commitments that undermine the performance of the phone, for example by depleting battery power. It is essential to manage the sleep cycle of sensing components in order to trade off the amount of battery consumed [48]. Nonetheless, smartphone's battery life is always low, which could hinder its acceptance. This is not a minor problem, especially considering that the system is intended for older people with impaired mobility. Thirdly, there is a need for easy-to-use smartphones and here we are in the hands of manufacturers. The potential market of the applications for people with low technical skills will influence the development of adapted devices. Nonetheless, fall detectors are unlikely to reach in the near future the robustness and stability achieved by other assistive technologies such as press-for-help devices.

\section{Issue 2: Privacy concerns}

Privacy concerns of sensor-based systems, and fall detectors are, have been a hot topic [61]. Of course, not all types of sensors are equally vulnerable: context-aware systems in general, and vision-based systems in particular, are much more prone to privacy concerns than, for example, body-worn acceleration-based devices. In any case, the protection of sensitive context data must be guaranteed [62]. Privacy problems should not prevent the potential benefits of assistive technologies as, at the same time, privacy cannot be sacrificed in order to bring about other benefits [63]. In general, studies on fall detection usually lack strategies to ensure data privacy. This shows that they are still far from a real-life deployment. 
Issue 3: Comparison among different techniques: public data bases

Comparing different approaches is difficult because each author obtains data in a different way: types of simulated falls and ADL, position of the detector, sampling frequency, temporal length of signal, extracted features, etc. The research focus should be not only on the algorithm to be used but also on the way signals are acquired and treated before feeding a classifier. A public database with accelerometer signals and videos of people falling could help to compare different methods and to improve the reproducibility of the results. Sharing source code of the algorithms would also be a valuable option.

\section{Issue 4: Real-life falls}

Most studies use data of simulated ADL and falls from young or mature people. Even assuming they were made publicly available for a fair comparison among different methods, it is unclear whether the simulated activities are representative of their real counterparts. Since it is not acceptable to subject older people to simulated falls, the evaluation of the detectors is severely limited. Only few studies present acceleration data from the real-life falls of older people [64,65], but the number of events recorded remain low. In addition, the mechanisms of the falls are not known as they could not be accurately documented [36].

\section{Conclusion}

In conclusion, fall detection is a complex process for which currently there is not a standardized solution. Fall detectors are essential in order to provide a rapid assistance and to prevent fear of falling and their adverse health consequences. This review provides a classification for fall detectors from the analysis of several studies, examines their evolution over time, and ultimately identifies the challenges, issues and trends in fall detection systems.

The number of studies in vision-based systems is still increasing. Besides, there is a new trend towards the integration of fall detectors into smartphones, but their use in real-world scenarios can still be compromised by the factors highlighted in this paper. Both biomedical engineers and clinicians should become aware of the limitations and potential of fall detection systems.

Abbreviations

ADL: Activities of daily living; SE: Sensitivity; SP: Specificity; TBM: Threshold-based method; MLM: Machine Learning Method.

Competing interests

The authors declare that they have no competing interests.

Authors' contributions

$\mathrm{RI}$ and CM carried out the research and drafted the manuscript. IP participated in its design, performed the statistical analysis and revised it critically for important intellectual content. All authors read and approved the final manuscript.

\section{Acknowledgments}

This work was supported by the "European Social Fund", the "Departamento de Ciencia, Tecnología y Universidad, Gobierno de Aragón" and the "Departamento de Industria e Innovación, Gobierno de Aragón (CTPP 11/12 sMartxan basic)".

Received: 9 April 2013 Accepted: 1 July 2013

Published: 6 July 2013

References

1. World Health Organization: Global report on falls prevention in older age. [http://www.who.int/ageing/publications/

Falls_prevention7March.pdf]

2. Friedman SM, Munoz B, West SK, Rubin GS, Fried LP: Falls and Fear of Falling: Which Comes First? A Longitudinal Prediction Model Suggests Strategies for Primary and Secondary Prevention. J Am Geriatr Soc 2002, 50:1329-1335. 
3. Scheffer AC, Schuurmans MJ, van Dijk N, van der Hooft T, de Rooij SE: Fear of falling: measurement strategy, prevalence, risk factors and consequences among older persons. Age Ageing 2008, 37:19-24.

4. Brownsell S, Hawley MS: Automatic fall detectors and the fear of falling. J Telemed Telecare 2004, 10:262-266.

5. Rubenstein LZ, Josephson KR: The epidemiology of falls and syncope. Clin Geriatr Med 2002, 18:141-58.

6. Tinetti MD, Liu WL, Claus EB: Predictors and prognosis of inability to get up after falls among elderly persons. J Am Med Assoc 1993, 269(1):65-70.

7. Lord SR, Sherrington C, Menz HB: Falls in older people. Risk, factors and strategies for prevention. Cambridge: Cambridge University Press; 2001.

8. Noury N, Fleury A, Rumeau P, Bourke AK, Laighin GO, Rialle V, Lundy JE: Fall detection - principles and methods In Proceedings of the Annual International Conference of the IEEE Engineering in Medicine and Biology Society. Lyon: Institute of Electrical and Electronics Engineers; 2007:1663-1666. doi:10.1109/IEMBS.2007.4352627. http://ieeexplore. ieee.org/xpl/login.jsp?tp=\&arnumber=4352627\&url=http\%3A\%2F\%2Fieeexplore.eeee.org\%2Fxpls\%2Fabs_all.jsp\% 3Farnumber\%3D4352627.

9. Bagala F, Becker C, Cappello A, Chiari L, Aminian K, Hausdorff JM, Zijlstra W, Klenk J: Evaluation of Accelerometer-Based Fall Detection Algorithms on Real-World Falls. PLoS One 2012, 7:e37062.

10. Noury N, Rumeau P, Bourke AK, OLaighin G, Lundy JE: A proposal for the classification and evaluation of fall detectors. Irbm 2008, 29:340-349.

11. Perry JT, Kellog S, Vaidya SM, Youn JH, Ali H, Sharif H: Survey and evaluation of real-time fall detection approaches. In Proceedings of the 6th International Symposium High-Capacity Optical Networks and Enabling Technologies. Alexandria: Institute of Electrical and Electronics Engineers; 2009:158-164. doi:10.1109/HONET.2009.5423081. http://ieeexplore.ieee. org/xpl/login.jsp?tp=\&arnumber=5423081\&url=http\%3A\%2F\%2Fieeexplore.ieee.org\%2Fxpls\%2Fabs_all.jsp\% 3Farnumber\%3D5423081.

12. Mubashir M, Shao L, Seed L: A survey on fall detection: Principles and approaches. Neurocomputing 2012, 100:144-152.

13. Parikh R, Mathai A, Parikh S, Sekhar GC, Thomas R: Understanding and using sensitivity, specificity and predictive values. Indian J Ophthalmol 2008, 56:45-50.

14. Rougier C, Meunier J, St-Arnaud A, Rousseau J: Robust video surveillance for fall detection based on human shape deformation. IEEE Trans Circuits Syst for Video Technol 2011, 21:611-622.

15. Miaou SG, Sung PH, Huang CY: A customized human fall detection system using omni-camera images and personal information. In Proceedings of the 1st Distributed Diagnosis and Home Healthcare Conference. Arlington: Institute of Electrical and Electronics Engineers; 2006:39-42. doi:10.1109/DDHH.2006.1624792. http://ieeexplore. ieee.org/xpl/articleDetails.jsp?arnumber=1624792.

16. Fu Z, Delbruck T, Lichtsteiner P, Culurciello E: An address-event fall detector for assisted living applications. IEEE Trans Biomed Circuits Syst 2008, 2:88-96.

17. Hazelhoff L, Han J, de With PHN: Video-based fall detection in the home using principal component analysis In Proceedings of the 10th International Conference on Advanced Concepts for Intelligent Vision Systems. Edited by Bland-Talon J, Bourennane S, Philips W, Popescu D, Scheunders P. Juan-les-Pins: Springer-Verlag Berlin; 2008:298-309. doi:10.1007/978-3-540-88458-3_27. http://citeseerx.ist.psu.edu/viewdoc/summary?doi=10.1.1.139.4748.

18. Mastorakis G, Makris D: Fall detection system using Kinect's infrared sensor. J Real-Time Image Proc 2012:1-12. doi:10.1007/s1 1554-012-0246-9. http://link.springer.com/article/10.1007\%2Fs11554-012-0246-9.

19. Cucchiara R, Rita H, Prati A, Andrea O, Vezzani R, Roberto C: A multi-camera vision system for fall detection and alarm generation. Expert Syst 2007, 24:334-345.

20. Lee T, Mihailidis A: An intelligent emergency response system: preliminary development and testing of automated fall detection. J Telemed Telecare 2005, 11:194-198.

21. Vishwakarma V, Mandal C, Sural S: Automatic detection of human fall in video. Lect Notes Comput Sci Pattern Recognit Mach Intell 2007, 4815:616-623.

22. Anderson D, Luke RH, Keller JM, Skubic M, Rantz M, Aud M: Linguistic summarization of video for fall detection using voxel person and fuzzy logic. Comput Vis Image Underst 2009, 113:80-89.

23. Liu CL, Lee CH, Lin PM: A fall detection system using k-nearest neighbor classifier. Expert Syst Appl 2010, 37:7174-7181.

24. Diraco G, Leone A, Siciliano P: An active vision system for fall detection and posture recognition in elderly healthcare. In Conference \& Exhibition: Design, Automation \& Test in Europe. Dresden: European Design and Automation Association; 2010:1536-1541. doi:10.1109/DATE.2010.5457055. http://ieeexplore.ieee.org/xpl/login.jsp? $\mathrm{tp}=$ \&arnumber $=5457055 \&$ url=http\%3A\%2F\%2Fieeexplore.eee.org\%2Fxpls\%2Fabs_all.jpp\%3Farnumber\%3D5457055.

25. Tzeng HW, Chen MY, Chen JY: Design of fall detection system with floor pressure and infrared image. In Proceedings of the International Conference on System Science and Engineering. Taipei: Institute of Electrical and Electronics Engineers; 2010:131-135. doi:10.1109//CSSE.2010.5551751. http:/ieeexplore.eee.org/xpl/login.jsp?tp=\&arnumber=5551751\&url=http\% 3A\%2F\%2Fieeexplore.ieee.org\%2Fxpls\%2Fabs_all.jsp\%3Farnumber\%3D5551751.

26. Edgcomb A, Vahid F: Privacy perception and fall detection accuracy for in-home video assistive monitoring with privacy enhancements. Spec Interest Group Health Inform Rec 2012, 2(2):6-15.

27. Zhang C, Tian Y, Capezuti E: Privacy preserving automatic fall detection for elderly using RGBD cameras In Proceedings of the $13^{\text {th }}$ International Conference on Computers Helping People with Special Needs. Edited by Miesenberger K, Karshmer A, Penaz P, Zagler W. Linz: Springer-Verlag Berlin; 2012:625-633. doi:10.1109/ICSSE.2010.5551751. http://ieeexplore.ieee.org/xpl/login.jsp?tp=\&arnumber=5551751\&url=http\%3A\%2F\%2Fieeexplore.ieee.org\%2Fxpls\% 2Fabs_all.jsp\%3Farnumber\%3D5551751.

28. Rimminen $\mathrm{H}$, Lindström J, Linnavuo $\mathrm{M}$, Sepponen R: Detection of falls among the elderly by a floor sensor using the electric near field. IEEE Trans Inf Technol Biomed 2010, 14:1475-1476.

29. Li Y, Ho KC, Popescu M: A microphone array system for automatic fall detection. IEEE Trans Biomed Eng 2012, 59:1291-1301.

30. Mann S: Wearable Computing. http://www.interaction-design.org/encyclopedia/wearable_computing.html. 
31. Culhane KM, O'Connor M, Lyons D, Lyons GM: Accelerometers in rehabilitation medicine for older adults. Age Ageing 2005, 34:556-560

32. Alpaydin E: Introduction to Machine Learning. New Haven: The MIT Press; 2004.

33. Lindemann U, Hock A, Stuber M, Keck W, Becker C: Evaluation of a fall detector based on accelerometers: A pilot study. Med Biol Eng Comput 2005, 43:548-551.

34. Chen J, Kwong K, Chang D, Luk J, Bajcsy R: Wearable Sensors for Reliable Fall Detection. In Proceedings of the IEEE Engineering in Medicine and Biology 27th Annual Conference. Shanghai: Institute of Electrical and Electronics Engineers; 2005:1-4. doi:10.1109/IEMBS.2005.1617246. http://ieeexplore.iee.org/xpl/login.jsp? tp=\&arnumber $=1617246 \&$ url=http\%3A\%2F\%2Fieeexplore.ieee.org\%2Fxpls\%2Fabs_all.jsp\%3Farnumber\%3D 1617246

35. Bourke A, O'Brien J, Lyons G: Evaluation of a threshold-based triaxial accelerometer fall detection algorithm. Gait Posture 2007, 26:194-199.

36. Kangas M, Konttila A, Lindgren P, Winblad I, Jms T: Comparison of low-complexity fall detection algorithms for body attached accelerometers. Gait Posture 2008, 28:285-291.

37. Kangas M, Vikman I, Wiklander J, Lindgren P, Nyberg L, Jämsä T: Sensitivity and specificity of fall detection in people aged 40 years and over. Gait Posture 2009, 29:571-574.

38. Li Q, Stankovic JA, Hanson M, Barth A, Lach J: Accurate, fast fall detection using gyroscopes and accelerometerderived posture information. In Proceedings of the 6th International Workshop on Wearable and Implantable Body Sensor Networks. Edited by Lo B, Mitcheson P. Berkeley; 2009:138-143. doi:10.1109/BSN.2009.46. http://ieeexplore. ieee.org/xpl/login.jsp?tp=\&arnumber=5226903\&url=http\%3A\%2F\%2Fieeexplore.ieee.org\%2Fxpls\%2Fabs_all.jsp\% 3Farnumber\%3D5226903.

39. Bianchi F, Redmond SJ, Narayanan MR, Cerutti S, Lovell NH: Barometric pressure and triaxial accelerometry-based falls event detection. IEEE Trans Neural Syst Rehabil Eng 2010, 18:619-627.

40. Bourke AK, de Ven V, Gamble M, O'Connor R, Murphy K, Bogan E, McQuade E, Finucane P, OLaighin G, Nelson J: Assessment of waist-worn tri-axial accelerometer based fall-detection algorithms using continuous unsupervised activities. In Proceedings of the Annual International Conference of the IEEE Engineering in Medicine and Biology Society. Buenos Aires: Institute of Electrical and Electronics Engineers; 2010:2782-2785. doi:10.1109/ IEMBS.2010.5626364. http://ieeexplore.ieee.org/xpl/login.jsp?tp=\&arnumber=5626364\&url=http\%3A\%2F\% 2Fieeexplore.ieee.org\%2Fiel5\%2F5608545\%2F5625939\%2F05626364.pdf\%3Farnumber\%3D5626364.

41. Lai CF, Chang SY, Chao HC, Huang YM: Detection of cognitive injured body region using multiple triaxial accelerometers for elderly falling. IEEE Sensors J 2011, 11:763-770.

42. Shan S, Yuan T: A wearable pre-impact fall detector using feature selection and support vector machine. In Proceedings of the IEEE 10th International Conference on Signal Processing. Beijing: Institute of Electrical and Electronics Engineers; 2010:1686-1689. doi:10.1109/ICOSP.2010.5656840. http://ieeexplore.ieee.org/xpl/login.jsp?

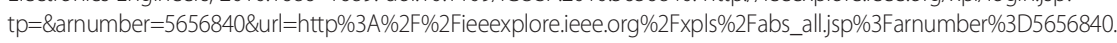

43. Yuwono M, Moulton B, Su S, Celler B, Nguyen H: Unsupervised machine-learning method for improving the performance of ambulatory fall-detection systems. Biomed Eng Online 2012, 11:1-11.

44. Kerdegari H, Samsudin K, Ramli AR, Mokaram S: Evaluation of fall detection classification approaches. In Proceedings of the 4th International Conference on Intelligent and Advanced Systems. Kuala Lumpur: Institute of Electrical and Electronics Engineers; 2012:131-136. do:10.1109//CIAS.2012.6306174. http://ieeexplore.ieee.org/xp//login.jsp? $\mathrm{tp}=\&$ arnumber $=6306174 \&$ url=http\%3A\%2F\%2Fieeexplore.eee.org\%2Fxpls\%2Fabs_all.jpp\%3Farnumber\%3D6306174.

45. Zhang T, Wang J, Xu L, Liu P: Fall detection by wearable sensor and one-class SVM algorithm. In Lecture Notes in Control and Information Science, Volume 345. Edited by Huang DS, Li K, Irwin GW. Berlin Heidelberg: Springer; 2006:858-863.

46. Doukas C, Maglogiannis I, Tragkas F, Liapis D, Yovanof G: Patient Fall Detection using Support Vector Machines. Int Fed Inf Process 2007, 247:147-156.

47. Cheng J, Chen X, Shen M: A framework for daily activity monitoring and fall detection based on surface electromyography and accelerometer signals. IEEE J Biomed and Health Inform 2013, 17(1):38-45.

48. Lane N, Miluzzo E, Lu H, Peebles D, Choudhury T, Campbell A: A survey of mobile phone sensing. IEEE Commun Mag 2010, 48:140-150.

49. Sposaro F, Tyson G: iFall: an Android application for fall monitoring and response. In Proceedings of the Annual International Conference of the IEEE Engineering in Medicine and Biology Society. Minneapolis: Institute of Electrical and Electronics Engineers; 2009:6119-6122. doi:10.1109/IEMBS.2009.5334912. http://ieeexplore.ieee.org/xpl/ articleDetails.jsp?arnumber $=5334912$.

50. Dai J, Bai X, Yang Z, Shen Z, Xuan D: Mobile phone-based pervasive fall detection. Pers Ubiquitous Comput 2010 14:633-643.

51. Lopes IC, Vaidya B, Rodrigues J: Towards an autonomous fall detection and alerting system on a mobile and pervasive environment. Telecommun Syst 2011, 48:1-12.

52. Lee RTW, Carlisle AJ: Detection of falls using accelerometers and mobile phone technology. Age Ageing 2011, 0:1-7.

53. Fang SH, Liang YC, Chiu KM: Developing a mobile phone-based fall detection system on android platform. In Proceedings of the Conference on Computing, Communications and Applications. Hong Kong: Institute of Electrical and Electronics Engineers; 2012:143-146. doi:10.1 109/ComComAp.2012.6154019. http://ieeexplore ieee.org/xpl/login.jsp?tp=\&arnumber=6154019\&url=http\%3A\%2F\%2Fieeexplore.ieee.org\%2Fiel5\%2F6145284\% 2F6153941\%2F06154019.pdf\%3Farnumber\%3D6154019.

54. Albert MV, Kording $\mathrm{K}$, Herrmann M, Jayaraman A: Fall classification by machine learning using mobile phones. PLoS One 2012, 7:e36556.

55. Abbate S, Avvenuti M, Bonatesta F, Cola G, Corsini P, Vecchio A: A smartphone-based fall detection system. Pervasive Mob Comput 2012, 8:883-899.

56. Google Play. [https://play.google.com/store?hl=en]

57. Bagchi KK, Kirs P, Lopez F: The impact of price decreases on telephone and cell phone diffusion. Inf Manag 2008, 45:183-193. 
58. Roupa Z, Nikas M, Gerasimou E, Zafeiri V, Giasyrani L, Kazitori E, Sotiropoulou P: The use of technology by the elderly. Health Sci J 2010, 4:118-126.

59. Kurniawan S: Older people and mobile phones: A multi-method investigation. Int J Human-Comput Stud 2008, 66:889-901.

60. Plaza I, Martin L, Martin S, Medrano C: Mobile applications in an aging society: Status and trends. J Syst Softw 2011, 84:1977-1988.

61. Drost C: Privacy in context-aware systems. [http://www.utwente.nl/ewi/asna/assignments/completed/drost.pdf]

62. Baldauf M: A survey on context-aware systems. Int J Ad Hoc and Ubiquitous Comput 2007, 2(4):263-277.

63. Sensors and In-Home Collection of Health Data: A Privacy by Design Approach. [http://www.ipc.on.ca/images/ Resources/pbd-sensor-in-home.pdf]

64. Kangas M, Vikman I, Nyberg L, Korpelainen R, Lindblom J, Jms T: Comparison of real-life accidental falls in older people with experimental falls in middle-aged test subjects. Gait Posture 2012, 35:500-505.

65. Klenk J, Becker C, Lieken F, Nicolai S, Maetzler W, Alt W, Zijlstra W, Hausdorff JM, van Lummel RC, Chiari L, Lindemann U: Comparison of acceleration signals of simulated and real-world backward falls. Med Eng Phys 2011, 33:368-373.

66. Degen T, Jaeckel H, Rufer M, Wyss S: SPEEDY: A fall detector in a wrist watch. In Proceedings of the 7th International Symposium on Wearable Computers. New York: IEEE Computer Society; 2003:184-187. doi:10.1109/ ISWC.2003.1241410. http://ieeexplore.ieee.org/xpl/login.jsp?tp=\&arnumber=1241410\&url=http\%3A\%2F\% 2Fieeexplore.ieee.org\%2Fxpls\%2Fabs_all.jsp\%3Farnumber\%3D1241410.

doi:10.1186/1475-925X-12-66

Cite this article as: Igual et al:: Challenges, issues and trends in fall detection systems. BioMedical Engineering OnLine 2013 12:66.

\section{Submit your next manuscript to BioMed Central and take full advantage of:}

- Convenient online submission

- Thorough peer review

- No space constraints or color figure charges

- Immediate publication on acceptance

- Inclusion in PubMed, CAS, Scopus and Google Scholar

- Research which is freely available for redistribution

Submit your manuscript at www.biomedcentral.com/submit 